\title{
ZNACZENIE ODKRYĆ W CHOTYŃCU (POŁUDNIOWO-WSCHODNIA POLSKA) DLA INTERPRETACJI PROCESÓW KULTUROWO-HISTORYCZNYCH NA ZACHODNIM WOŁYNIU I PODOLU (UKRAINA) WE WCZESNEJ EPOCE ŻELAZA
}

\author{
THE SIGNIFICANCE OF DISCOVERIES FROM CHOTYNIEC \\ (SOUTH-EASTERN POLAND) FOR THE INTERPRETATION OF \\ CULTURAL AND HISTORICAL PROCESSES IN WESTERN VOLHYNIA \\ AND PODOLIA (UKRAINE) IN THE EARLY IRON AGE
}

\begin{abstract}
Abstrakt: W latach 2016-2019 przeprowadzono pierwszy etap wykopalisk na grodzisku w Chotyńcu (południowo-wschodnia Polska, $8 \mathrm{~km}$ od obecnej granicy polsko-ukraińskiej). Odkryte materiały pozwalają łączyć je z leśnostepowym wariantem scytyjskiego kręgu kulturowego. Na grodzisku zbadano zolnik, w warstwach którego znaleziono pokaźny zespół przedmiotów. Na plan pierwszy wysuwają się fragmenty greckich amfor na wino, liczne militaria i ozdoby metalowe o scytyjskiej proweniencji. W okolicy grodziska zidentyfikowano także osady z podobnymi przedmiotami. Można już mówić o całym mikroregionie - aglomeracji, której identyfikacja ma kluczowe znaczenie dla interpretacji sytuacji kulturowej we wczesnej epoce żelaza na obszarze południowo-wschodniej Polski oraz przyległych terenów Ukrainy - Wołynia i zachodniego Podola. W artykule rozpatrywane są „wschodnie” grupy: leżnicka, czerepińsko-łagodowska i zachodniopodolska w kontekście odkryć w Chotyńcu.
\end{abstract}

Słowa kluczowe: wczesna epoka żelaza, Wołyń, Podole, Scytia, Chotyniec, relacje kulturowe

\begin{abstract}
The first stage of excavations at the Chotyniec hillfort in southeastern Poland $(8 \mathrm{~km}$ from today's Polish-Ukrainian border), carried out in 2016-2019, has produced an assemblage of finds that link it to the forest-steppe variant of the Scythian Cultural Circle. A cult area (zol$n i k$ ) was investigated, discovering fragments of Greek wine amphorae, an abundance of weapons and personal metal accessories of Scythian provenance. Settlements with similar assemblages of finds located around the hillfort have been identified as a micro-region of key importance for the interpretation of the cultural situation in the early Iron Age of a territory covering the regions of Volhynia and western Podolia - today in southeastern Poland and the adjoining areas of Ukraine. The article discusses the "eastern" groups: Lezhnica, Cherepin-Lagodiv and Western Podolian, in the context of the Chotyniec discoveries.
\end{abstract}

Keywords: Early Iron Age, Volhynia, Podolia, Scythia, Chotyniec, cultural relations

a Prof. dr hab. Sylwester Czopek, Instytut Archeologii Uniwersytetu Rzeszowskiego, ul. Moniuszki 10,35-015 Rzeszów, sycz@archeologia.rzeszow.pl, ORCID iD: https://orcid.org/0000-0003-3762-4215. 


\section{WSTEP $^{1}$}

Sytuacja kulturowa na zachodnim Wołyniu i sąsiadującym z nim Podolu we wczesnej epoce żelaza od połowy lat siedemdziesiątych XX w. wydawała się być uporządkowana dzięki syntetycznej monografii autorstwa Larysy Kruszelnyćkiej. Książka ta (Krušel'nic'ka 1976) zapoczątkowała/ugruntowała trwałą obecność w systematyce archeologicznej trzech regionalnych jednostek - grup: mogilańskiej, czerepińsko-łagodowskiej i leżnickiej. Od ponad 40 lat ugrupowania te są stale obecne w literaturze, a to ze względu na powiększającą się bazę źródłową, a to potrzebę bardziej pogłębionej refleksji w szerszym wyjaśnianiu procesów kulturowych na granicy Europy środkowej i wschodniej (Krušel'nic'ka 1990, s. 143-151; Węgrzynowicz 2001, s. 77-80; Czopek 2018, s. 193-210). Obydwa aspekty są w oczywisty sposób ze sobą związane. Jednak bezpośrednim powodem powstania artykułu są wyniki badań grodziska w Chotyńcu, pow. jarosławski - stanowiska oddalonego od obecnej granicy polsko-ukraińskiej o $8 \mathrm{~km}$. Jest ono systematycznie badane od 2016 r. (Czopek i in. 2017; Czopek 2019; Trybała-Zawiślak 2019, s. 264-290). Uzyskane do tej pory informacje źródłowe, powiązane z wcześniejszymi badaniami (Czopek i in. 2018), pozwalają mówić o wyjątkowym znaczeniu całej aglomeracji (mikroregionu) chotynieckiej, jako wysuniętej najdalej na zachód enklawy leśnostepowego wariantu scytyjskiego kręgu kulturowego. Ten niezwykle interesujący mikroregion składa się z centralnie położonego grodziska w Chotyńcu i co najmniej kilkunastu osad otwartych znajdujących się w jego otoczeniu. W tej chwili można wprawdzie już mówić o zaawansowanym stopniu znajomości źródeł z tego terenu, ale do pełnego ich poznania jest jeszcze daleko. Dotyczy to na przykład samego grodziska, w obrębie którego zbadano zolnik i częściowo wały, zachowane w różnym stopniu ze względu na współczesne zniszczenia. Wyniki badań prowadzonych w Chotyńcu mają bardzo duże znaczenie dla wyjaśnienia procesów kulturowych we wczesnej epoce żelaza zarówno na zachód od aglomeracji (tarnobrzeska kultura łużycka), jak i na wschód (najbliższa grupa czerepińsko-łagodowska i ewentualnie leżnicka). Przedmiot naszych rozważań ograniczymy właśnie do tych wschodnich relacji. Grupa mogilańska zostanie tu tylko wspominana, z racji swych odrębności i odległości od aglomeracji chotynieckiej.

Niezbędnym kontekstem, zarówno w aspekcie chronologii, jak i relacji terytorialnych, będą przytoczone pokrótce uwagi o dwóch innych ugrupowaniach - kulturze wysockiej i grupie zachodniopodolskiej. W ostatnich latach opublikowano ważne prace, które korygują lub nawet dość gruntownie zmieniają dotychczasowe postrzeganie tych jednostek kulturowych (np. Bandrivs'kij 2014). Poza tym, w szerszym niż do tej pory zakresie należy brać pod uwagę także ogólne procesy kulturowo-historyczne zachodzące w starszej części wczesnej epoki żelaza (= HaC i HaD) w całej

1 Artykuł powstał w wyniku realizacji dwóch grantów badawczych Narodowego Centrum Nauki: nr 2013/09/B/HS3/04277, pt. „Przemiany kulturowo-osadnicze w dorzeczu rzeki Wiszni w epoce brązu i we wczesnej epoce żelaza w kontekście zmian prahistorycznej i wczesnośredniowiecznej ekumeny", oraz nr 2017/27/B/HS3/01460, pt. „Na granicy dwóch światów. Aglomeracja chotyniecka scytyjskiego kręgu kulturowego - etap I: badania terenowe”. 


\section{INTRODUCTION ${ }^{1}$}

In Larisa Krushelnytska's synthetic monograph treating on the early Iron Age in western Volhynia and neighboring Podolia, the cultural situation appeared to be well structured with three regional archaeological units: the Mogiliany, Cherepin-Lagodiv and Lezhnica groups, which she successfully introduced into the archaeological discourse (Krušel'nic'ka 1976). For over 40 years these groups have been present in the literature, on one hand because of a growing source base and, on the other, because of a broader and more in-depth reflection on the cultural processes taking place on the border between central and eastern European territories (Krušel'nic'ka 1990, pp. 143-151; Węgrzynowicz 2001, pp. 77-80; Czopek 2018, pp. 193-210). The two trends are evidently interconnected. Nonetheless, the present article is based directly on the archaeological excavations at the hillfort of Chotyniec in the Jarosław district of Poland, just $8 \mathrm{~km}$ from the Ukrainian border, carried out regularly since 2016 (Czopek et al. 2017; Czopek 2019; Trybała-Zawiślak 2019, pp. 264-290). The discoveries, considered in the context of earlier research (Czopek et al. 2018), argue in favor of the exceptional importance of the Chotyniec micro-region as the westernmost enclave of a forest-steppe variant of the Scythian cultural circle. This extremely interesting micro-region comprises the centrally located hillfort at Chotyniec and at least a few dozen unfortified settlements in its neighborhood. The progress in understanding sources from the region has been substantial, but there is still a long way to go. For instance, only a cult place (zolnik) and part of the embankments (differently preserved owing to modern disturbance) have been investigated inside the hillfort. The results of fieldwork at Chotyniec are of considerable significance for the interpretation of cultural processes taking place in the Early Iron Age both west of this agglomeration of sites (Lusatian culture from the Tarnobrzeg area) and east (the nearest Cherepin-Lagodiv group and possibly also the Lezhnica group). The current discussion will be restricted to the eastern relations, the Mogiliany group being referred to only in passing owing to its distinctiveness and distance from the Chotyniec agglomeration.

For a better understanding of the chronological context and territorial relations, it is necessary to discuss in brief two other groups, the Vysocka culture and the Western Podolian group. Two important recent studies have revised and even substantially changed perception of these cultural units (e.g. Bandrivs'kij 2014). One should also bring into consideration to a greater degree the broader cultural and historical processes at play throughout Europe in the beginning of the Early Iron Age $(=\mathrm{HaC}$ and $\mathrm{HaD})$, as well as introduce changes in the methodological approach. Describing cultures as stable structures is no longer satisfactory and there is a need to look for other forms of interpretation. An advanced study of the chrono-

1 The article is the outcome of two research grants awarded by Poland's National Science Centre: 2013/09/B/HS3/04277, "Cultural and settlement changes in the Wisznia river basin in the Bronze and early Iron Ages in the context of the prehistoric and early medieval ecumene", and 2017/27/B/ HS3/01460, "On the border of two worlds. The Chotyniec agglomeration of the Scythian cultural circle - stage I: fieldwork". 
Europie, a także potrzebę zmiany metodologicznej. Nie wystarcza już dziś ogólna charakterystyka kultur jako stabilnych struktur, ale należy poszukiwać innych dróg interpretacji. Zaawansowane studia chronologiczne sprzyjają rozumieniu relacji kulturowych jako bardziej dynamicznych, wpisanych w szersze, ogólnoeuropejskie konteksty (Dzięgielewski 2017). W takim podejściu przywiązanie do kultur i grup w ich tradycyjnym rozumieniu może być znaczącym balastem, który utrudnia nową interpretację.

Zanim przeanalizujemy problem zasygnalizowany w tytule niniejszej pracy, przedstawimy pokrótce aktualny stan badań nad interesującymi nas jednostkami kulturowymi - kulturą wysocką oraz grupami: czerepińską-łagodowską, leżnicką i zachodniopodolską, a także aglomeracją chotyniecką. Będzie to tylko zwrócenie uwagi na najważniejsze w stosunku do założonych celów fakty i problemy. Szczegółowa charakterystyka tych jednostek, znanych przecież z bogatej literatury, zajęłaby sporo miejsca gubiąc istotę rozważanego problemu. Szczególną rolę przypiszemy kwestiom chronologii, które wydają się kluczowe dla rozpatrzenia dość skomplikowanych relacji dotyczących przenikających się cech uważanych za dystynktywne dla poszczególnych ugrupowań i ich terytoriów. Wyjaśnienia wymaga pominięcie w tym zestawieniu grupy mogilańskiej (Dąbrowski 1972, s. 170; Krušel'nic'ka 1976, s. 72-82). Wynika to $z$ dużej odległości między Chotyńcem a terytorium tej jednostki (międzyrzecze Seretu i Słucza, do górnego dorzecza Bohu), a także nieco innego jej charakteru, odbiegającego dość wyraźnie od dwóch pozostałych ugrupowań.

\section{SYTUACJA KULTUROWA PRZED OKRESEM SCYTYJSKIM}

Dla zrozumienia znaczenia zmian wywołanych pojawieniem się na interesującym nas obszarze materiałów o proweniencji scytyjskiej, konieczne jest przybliżenie wcześniejszej sytuacji kulturowej. Pierwszą jednostką, która powinna być zaprezentowana jest kultura wysocka. Od czasów pierwszego monograficznego ujęcia autorstwa Tadeusza Sulimirskiego (1931) i mniej zaawansowanych studiów sprzed wielu lat (Bukowski 1966), jej interpretacja wyraźnie się zmieniła, co zawdzięczamy nowym źródłom, ale także studiom regionalnym. Nowe interpretacje dotyczą niemalże wszystkich cech, które wymienia się zwykle w charakterystyce kultur (Krušel'nic'ka 1976, s. 45-59; taż 1990, s. 115-122; Bandrivs'kij, Krušel'nic'ka 1998; Hozer 2005a; 2005b; Bandrivs'kij 2014, s. 185-243). Na początku należy zwrócić uwagę, że ekumena kultury wysockiej jest największą spośród wszystkich interesujących nas w tym opracowaniu ugrupowań. Można ją szacować na około 40 tys. $\mathrm{km}^{2}$ powierzchni (ryc. 1), rozciągającej się od górnego dorzecza Bugu, Styru i Ikwy oraz Horynia, a na południu sięgając do Dniestru (Hozer 2005b, s. 221-240, ryc. 1). Mykoła Bandriwśkyj sformułował ostatnio cztery cechy („oznaki”), które jego zdaniem mają decydować o ewentualnym zaliczeniu stanowiska lub materiałów do kultury wysockiej. Są to: 1 . przewaga inhumacji z wyprostowanymi na wznak szkieletami; 2. specyficzne cechy rytuału pogrzebowego, przejawiające się 
logical sequence opens the way to a better understanding of the relations between cultures in a more dynamic sense, embedded in a wider, pan-European context (Dzięgielewski 2017). Attachment to traditionally defined cultures and groups can be a significant ballast in this approach, hindering new interpretations.

A brief presentation of the current state of research on the cultural units in question, the Vysocka culture and the Cherepin-Lagodiv, Lezhnica and Western Podolian groups as well as the Chotyniec agglomeration, is essential before undertaking an interpretation of the cultural and historical processes of the early Iron Age in western Volhynia and Podolia, as indicated in the title of this paper. There is no need here for a full characteristic of these units in view of the extensive literature on the subject, hence the following will concentrate on the most important facts and research issues relevant to the present discussion. Questions of chronology in particular appear to be of key importance for understanding the rather complex issues of interpenetration of distinctive characteristics in the individual groups and their territories. The exclusion of the Mogiliany group should be justified (Dąbrowski 1972, p. 170; Krušel'nic'ka 1976, pp. 72-82) and the main reason for this is the distance of the territory of this unit (the interfluve of the Seret and Sluch, extending to the upper Boh river basin) from Chotyniec, as well as its character, quite distinctly different from the other two groups.

\section{THE CULTURAL SITUATION BEFORE THE SCYTHIAN PERIOD}

An understanding of the cultural background of the area in question is a prerequisite to discussing any changes that the influx of Scythian material culture could have generated. First, let us take a look at Vysocka culture, the interpretation of which has changed considerably since the original monograph by Tadeusz Sulimirski (1931) and some later less advanced studies (Bukowski 1966). New sources, as well as regional studies, have resulted in a new take on practically every single aspect characterizing this culture (Krušel'nic'ka 1976, pp. 45-59; eadem 1990, pp. 115-122; Bandrivs'kij, Krušel'nic'ka 1998; Hozer 2005a; 2005b; Bandrivs'kij 2014, pp. 185-243). The Vysocka culture ecumene is the largest of the groups considered, an estimated 40,000 $\mathrm{km}^{2}$ (Fig. 1), from the upper Bug, Styr, Ikva and Horyn in the north to the Dniester in the south (Hozer 2005b, pp. 221-240, Fig. 1). According to Mykola Bandrivskyi, there are four characteristics ("markers") determining the identification of a given site or assemblage as belonging to this particular culture: 1. a prevalence of inhumation burial with the bodies laid on the back; 2. specific elements of burial ceremonies such as positioning of the hands; 3 . ritual pottery and its decoration; 4. a well developed flint industry (Bandrivs'kij 2014, pp. 235-237). The domination of burial-related characteristics in this set is evident and should be emphasized in view of the fact that the burial customs of two of the groups under discussion (Lezhnica and Cherepin-Lagodiv) are poorly recognized. As for settlement in general and the actual dwelling sites, they are insufficiently investigated despite more settlements being known than cemeteries (Hozer 2005b, pp. 244-245). 


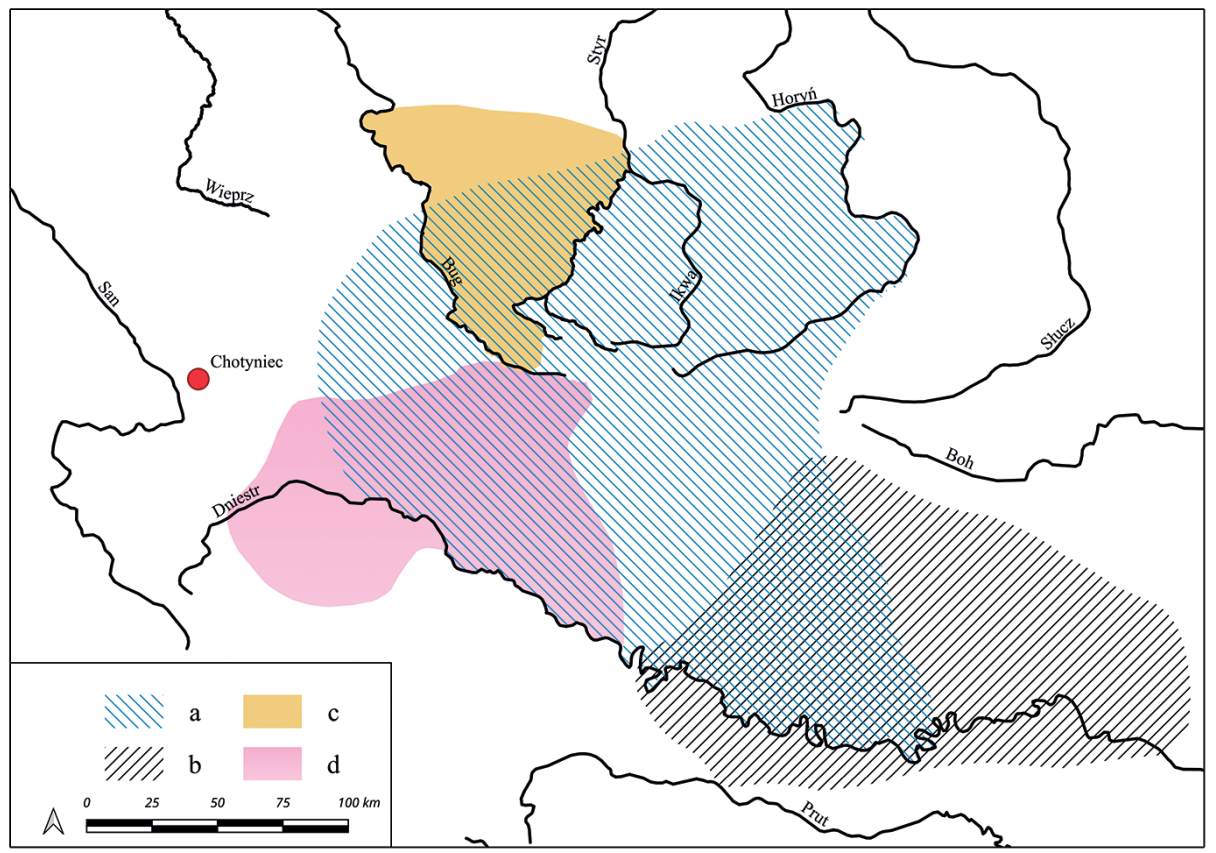

Ryc. 1. Mapa zgeneralizowanych zasięgów opisywanych jednostek kulturowych a - kultura wysocka; b - grupa zachodniopodolska; c - grupa leżnicka; d - grupa czerepińsko-łagodowska.

Wg Krušel'nic'kiej 1976, mapa III; Hozer 2005b, ryc. 1; Smirnovej 2004, ryc. 1; Ėbertsa 2012, ryc. 1; kontur kartogramu wykonano na podstawie mapy „Ukraïna” 1:2 500 000: DNVP Kartografiâ 2005

Fig. 1. Mapping the generalized territorial ranges of the cultural units in question a - Vysocka culture; b - Western Podolian group; $\mathrm{c}$ - Lezhnica group; $\mathrm{d}$ - Cherepin-Lagodiv group.

After Krušel'nic'ka 1976, map III; Hozer 2005b, Fig. 1; Smirnova 2004, Fig. 1; Ėberts 2012, Fig. 1; the contour of the cartogram is based on the map "Ukraina" 1:2 500 000: DNVP Kartografiâ 2005

w sposobie układania rąk zmarłego; 3 . rytualna ceramika i jej zdobienie; 4. dobrze rozwinięte krzemieniarstwo (Bandrivs'kij 2014, s. 235-237). Widzimy więc wyraźną dominację cech funeralnych, co należy podkreślić, bo obrządek dwóch innych interesujących nas grup (leżnickiej i czerepińsko-łagodowskiej) jest słabo rozpoznany. Niezbyt wiele wiemy o osadnictwie i osadach. Tych ostatnich znamy co prawda więcej niż cmentarzysk (Hozer 2005b, s. 244-245), ale są one zbadane w bardzo małym zakresie.

Zasygnalizowaliśmy już, że duże znaczenie w naszych rozważaniach ma chronologia. Od czasów pierwszej monografii (Sulimirski 1931) w datowaniu kultury wysockiej dokonała się swoista, kilkuetapowa rewolucja. Pierwotnie ustalone ramy czasowe, określane na IX/VIII-I w. p.n.e., są już nie do przyjęcia. Uwaga ta dotyczy zarówno początku, jak i końca tego ugrupowania. Zbigniew Bukowski (1966), przychylając się do zdania archeologów ukraińskich, odnosił czas występowania tej jednostki od XI/X do VI w. p.n.e. Taką chronologię przyjęła także L. Kruszelnyćka 
The significance of chronology for the present discussion has already been noted. In this respect, the dating of Vysocka culture has undergone, step by step, a veritable revolution ever since the presentation of the first chronological framework establishing a date in the $9^{\text {th }} / 8^{\text {th }}-1^{\text {st }} c$. BC (Sulimirski 1931). This is no longer acceptable, neither for the onset nor for the termination of this culture. Zbigniew Bukowski (1966) followed Ukrainian archaeologists in dating the unit from the $11^{\text {th }} / 10^{\text {th }}$ to the $6^{\text {th }}$ centuries BC, a chronology adopted also by Krushelnytska (Krušel'nic'ka 1976, pp. 57-58). Jan Dąbrowski placed the beginnings of the culture in the same time (Dąbrowski 1972, pp. 164-170, Table 2). In 1998, Bandrivskyi and Krushelnytska proposed a significant revision of the early phase, pushing it up to the $12^{\text {th }} \mathrm{C}$., while keeping the end in the $6^{\text {th }}$ (Bandrivs'kij, Krušel'nic'ka 1998). Their findings were based on the results of investigations at the cemetery in Petrikov near Ternopil (Bandrivs'kij 2002), which demonstrated beyond doubt the synchronous origins of the eastern groups of Lusatian culture (the Tarnobrzeg branch in particular) and Vysocka culture (Godlewski 2005; Bandrivs'kij 2014, pp. 205-206). Bandrivskyi's suggestion to narrow down the date for the end of the culture to the mid $6^{\text {th }} \mathrm{c}$. (Bandrivs'kij 2002, pp. 199) appears purely cosmetic when considered in the light of his curious hypothesis from just two years later, placing the proto-Wysocki stage of the culture (without detailed sourcing) in the Early Bronze Age (19 th c. BC) and assigning the terminal stages to the $10^{\text {th }} \mathrm{c}$. BC (Bandrivs'kij 2005). In his most recent publication, however, Bandrivskyi returned to a modified version of the 1998 dating, presenting a phased, three-stage development falling between $\mathrm{BrD}$ and $\mathrm{HaC} 2$ (Bandrivs'kij 2014, pp. 156). From a methodological point of view, it is essential to note that the systemic divisions into the Bronze and Early Iron Ages of O. Montelius or P. Reinecke never held true in the archaeology of eastern Europe. For the Bronze Age (in the Central European sense) there is still some justification for using the Alpine-Danubian model (Reinecke) because of the same types of bronze artifacts occurring in the archaeological record, but there is no such possibility for the Hallstatt period. Therefore, the only way is to calculate (compare) absolute dates (for example, in relation to the periodization proposed by M. Trachsel [2004]). When synchronizing cultures based on different assumptions, one needs to keep in mind that particular phases in relative chronology systems are defined by the typical materials in these phases and not their absolute dating. Of particular interest for the present discussion is the way in which the terminal stage of Vysocka culture, referred to as the $\mathrm{HaB} 3$, has been described as a "dilution of all of the chief markers" (Bandrivs'kij 2014, pp. 238). Enclaves of the culture could have still survived in difficult to reach microregions in the $\mathrm{HaCl}$ phase, which could be related to the population dislocation in eastern and central Europe triggered by raiding Kimmerian tribes (Chochorowski 1993). Single artifacts and even whole sets of Kimmerian objects found in territories ascribed to the Vysocka culture may be proof of this scenario, for example, the rich equestrian kit recently discovered at Birki Wielkie near Ternopil (Bandrivs'kij et al. 2012; Bandrivs'kij 2014, pp. 283-287). This set without a clear interpretation (hoard? grave goods?) includes elements of horse harness: bits, cheeks and phalerae, which are undoubtedly of Kimmerian origin and dated to the turn of the $9^{\text {th }}$ and into the 
(Krušel'nic'ka 1976, s. 57-58), a Jan Dąbrowski identycznie określał początek tej kultury (Dąbrowski 1972, s. 164-170, zestawienie 2). W 1998 r. M. Bandriwśkyj i L. Kruszelnyćka zaproponowali znaczącą korektę w odniesieniu do fazy wczesnej, według której jednostka ta miała powstać w wieku XII i zaniknąć w VI (Bandrivs'kij, Krušel'nic'ka 1998). Wniosek ten pojawił się po badaniach cmentarzyska w Petrykowie koło Tarnopola (Bandrivs'kij 2002), które jednoznacznie wykazały synchroniczność genezy wschodnich ugrupowań kultury łużyckiej (szczególnie tarnobrzeskiej kultury łużyckiej) i wysockiej (Godlewski 2005; Bandrivs'kij 2014, s. 205-206). Propozycja z roku 2002 (Bandrivs'kij 2002, s. 199), polegająca na ograniczeniu czasu trwania okresu późnego do połowy VI w., wydaje się kosmetyczna w stosunku do dość oryginalnej tezy tego samego badacza opublikowanej zaledwie dwa lata później, według której tzw. etap protowysocki (bez szczegółowego określenia źródłowego) odnosi się już do wczesnej epoki brązu (XIX w. p.n.e.), a faza końcowa przypada na X w. p.n.e. (Bandrivs'kij 2005). W swej najnowszej pracy powrócił on jednak do zmodyfikowanej koncepcji z 1998 r., prezentując rozwój kultury wysockiej w ramach trzech faz, podzielonych na etapy, zawierający się między BrD a HaC2 (Bandrivs'kij 2014, s. 156). W związku z tym trzeba sformułować istotną uwagę metodyczną. Otóż, w archeologii wschodniej Europy w zasadzie nigdy nie funkcjonował podział epoki brązu i wczesnego żelaza, adekwatny do systemów O. Monteliusa czy P. Reineckego. O ile jeszcze w odniesieniu do epoki brązu (w rozumieniu środkowoeuropejskim) można mówić o możliwościach wykorzystywania schematu alpejsko-dunajskiego (Reinecke) z racji występowania takich samych typów zabytków brązowych, to w przypadku okresu halsztackiego już takich możliwości nie ma. Dlatego też jedyną podstawą jest przeliczanie (porównywanie) datowań absolutnych (np. w stosunku do periodyzacji zaproponowanej przez M. Trachsela [2004]). Trzeba zaznaczyć, że poszczególne fazy w systemach chronologii względnej definiują typowe dla nich materiały, a nie ich chronologia absolutna. Należy o tym pamiętać przy wszelkich próbach synchronizacji dokonywanych na bazie różnych przesłanek. Szczególnie interesujący nas, z punktu widzenia tematyki niniejszych rozważań, etap końcowy kultury wysockiej został określony jako okres (czas) „rozmywania całości głównych wyznaczników” (Bandrivs’kij 2014, s. 238) kultury wysockiej, odnoszony do $\mathrm{HaB3}$. W okresie $\mathrm{HaCl}$ mogły jeszcze funkcjonować enklawy „wysockie” w trudno dostępnych mikroregionach, co może mieć związek z niepokojami i przesunięciami ludnościowymi w Europie wschodniej i centralnej, spowodowanymi presją kimmeryjskich koczowników (Chochorowski 1993). Mogą o tym świadczyć znaleziska pojedynczych przedmiotów lub nawet ich zespołów o proweniencji kimmeryjskiej, znajdowane na terytorium przypisywanym do kultury wysockiej. Jako przykład można podać znaleziony niedawno, bogaty zestaw oporządzenia jeździeckiego z miejscowości Birki Wielkie koło Tarnopola (Bandrivs'kij i in. 2012; Bandrivs'kij 2014, s. 283-287). W tym zbiorze o niejasnej interpretacji (skarb?, inwentarz grobowy?) są wędzidła, pobocznice i falery, które jednoznacznie łączą się z horyzontem kimmeryjskim i mogą być datowane na przełom IX i VIII w. p.n.e. Ostateczny kres kultury wysockiej określa się na ostatnią ćwierć VIII w. p.n.e. (Bandrivs'kij 2014, s. 241-243). Takie datowanie wyklucza 
$8^{\text {th }} \mathrm{C}$. BC. Considering that the last quarter of the $8^{\text {th }} \mathrm{c}$. BC is now accepted as the end of Vysocka culture (Bandrivs'kij 2014, pp. 241-243), Scythian arms and ornaments can no longer be viewed as having an impact on this culture in its terminal stages, which was the case before. A few of the earliest artifacts could be dated to the end of the $8^{\text {th }}$ and early $7^{\text {th }} \mathrm{C}$. BC, and their broadest distribution was in the $2^{\text {nd }}$ half of the $7^{\text {th }}$ and $1^{\text {st }}$ half of the $6^{\text {th }}$ c. BC (Gawlik 2005, pp. 214-215). If not the Vysocka culture, then which group should they be linked to? The two most distinctive grave inventories (graves I and II from Rakiv Kut) have yielded numerous Scythian metal artifacts: nail-like earrings, pins with nail-shaped heads, pins with a massive head in the form of a spiral disk, torques with hammered terminals bent into a loop, spearheads, all dated to the $2^{\text {nd }}$ half of the $7^{\text {th }}$ and $1^{\text {st }}$ half of the $6^{\text {th }}$ centuries BC (Gawlik 2005 , p. 212). One should also agree with Bandrivskyi that the inhumation rites in these two graves do not reflect classical Vysocka culture funerary models, hence the evident attribution to the Western Podolian group in its earliest phase (Bandrivs'kij 2014, pp. 238, 307-308), already suggested before (Smirnova 2004, p. 411). The site lies on the Zbruch river, in a peripheral area of Vysocka culture, which is at the same time the center of the ecumene of the Western Podolian group established in the middle Dniester region from at least the mid- $7^{\text {th }} \mathrm{c}$. BC (see below).

The reported presence of most other metal artifacts of Scythian provenance in Vysocka culture contexts cannot be easily verified. A large group was presented in a 2005 publication (Gawlik 2005), which however included finds without determined context automatically associated with Vysocka culture because of the findspot, e.g., arrowheads from localities like Zvenikhorod, Jaseniv, Loshniv, Pochapi, Podzamche/Pid, Ternopil and Vikiny/Okuniny (Sulimirski 1931, pp. 91, 97-98, 108; Bukowski 1977, pp. 59-62, 81, 98, 119-120, 163; Węgrzynowicz 2001, p. 43). The case of the arrowheads and earrings from the cemetery at Lugove is also unclear. In his descriptions of cremation graves Nos 62 and 63, Sulimirski cited the old grave inventories mentioned by Mykhajlo Hrushevskyi as the only finds next to burnt human bones (Sulimirski 1931, pp. 69). Obviously, this group of artifacts of Scythian provenance, dated for the most part to the $6^{\text {th }} \mathrm{c}$. BC, need not (and even cannot) be linked to Vysocka culture. Tying these objects with Scythian infiltration is not a new idea; citing Ukrainian researchers, Bukowski (1966, pp. 97) wrote: “...the newcomers of this group [i.e., Western Podolian - S.C.] brought Vysocka settlement entirely under their domination, eliminating it as an independent cultural unit. The unrest preceding the decline of this group is signified by Scythian arrowheads of an archaic form, typical of the $7^{\text {th }}-6^{\text {th }}$ centuries BC, in Vysocka graves".

Another cultural unit, Holihrady culture, should be distinguished as occupying the zone in the Dniester river basin, south of Vysocka culture territory, in the Late Bronze and Early Iron Ages. Its ecumene reached the middle Dniester and upper Prut rivers (Otroŝenko 1998, pp. 420-421; Czopek 2010b, p. 361). Alternative designations in the literature (synonyms not only in terms of language, but also sources) include Thracian Hallstatt culture (Thracian Hallstatt/Hallstatt) and Gava-Holihrady complex (circle, culture) (Krušel'nic'ka, Maleev 1990). The lattermost name highlights connections with the Carpathian Basin, evident in the 
w oczywisty sposób wykorzystywanie scytyjskich militariów i ozdób, które uwzględniano dotychczas $w$ rozważaniach chronologicznych, łączących się ze schyłkiem tej kultury. Najstarsze, nieliczne, mogą pochodzić z końca VIII i początku VII w. p.n.e., a ich największe rozpowszechnienie przypada na 2 poł. VII i 1 poł. VI w. p.n.e. (Gawlik 2005, s. 214-215). Pojawia się zatem pytanie, z jakim ugrupowaniem należy je łączyć. Dwa najbardziej dystynktywne inwentarze (groby I i II z Rakowa Kąta) zawierają bardzo liczne metale o scytyjskiej proweniencji: zausznice gwoździowate, szpile z główką grzybkowatą (gwoździowatą), szpile z masywną główką zwiniętą $\mathrm{w}$ tarczkę spiralną, tordowany naszyjnik z rozklepanymi końcami zwiniętymi w uszko, grot oszczepu, pozwalające na ich datowanie na 2 poł. VII i 1 poł. VI w. p.n.e. (Gawlik 2005, s. 212). Zgodzić się przy tym należy z M. Bandriwśkim, że szkieletowy obrządek obydwu grobów odbiega od klasycznego schematu kultury wysockiej, stąd wyraźne wskazanie na przynależność ich do grupy zachodniopodolskiej, z jej najwcześniejszej fazy (Bandrivs'kij 2014, s. 238, 307-308), na co wskazywano już dawniej (Smirnova 2004, s. 411). Samo stanowisko jest zlokalizowane nad Zbruczem, w peryferyjnej strefie zasięgu kultury wysockiej, a jednocześnie w centrum ekumeny grupy zachodniopodolskiej, która właśnie co najmniej w połowie VII w. zajmuje całe środkowe dorzecze Dniestru (por. dalej).

Weryfikacja pozostałych przedmiotów metalowych o scytyjskiej proweniencji w kontekście ich ewentualnej przynależności do kultury wysockiej jest trudna. Spora ich część została uwzględniona w publikacji z 2005 r. (Gawlik 2005), jednak w tej grupie znalazły się również znaleziska bezkontekstowe, niejako zwyczajowo wiązane z kulturą wysocką tylko ze względu na miejsce znalezienia. Mowa tu np. o grocikach z takich miejscowości, jak: Dźwinogród/Zwenigorod, Jasionów, Łoszniów, Poczapy, Podzamcze, Tarnopol czy Wikiny/Okuniny (Sulimirski 1931, s. 91, 97-98, 108; Bukowski 1977, s. 59-62, 81, 98, 119-120, 163; Węgrzynowicz 2001, s. 43). Niejasna jest też kwestia grocików i zausznic z cmentarzyska w Czechach/ Ługowem. T. Sulimirski, cytując stary inwentarz polowy Myhajły Hruszewskiego, wymienia te zabytki w opisie grobów ciałopalnych nr 62 i nr 63, gdzie były ich jedynym wyposażeniem wśród spalonych kości (Sulimirski 1931, s. 69). Widzimy więc, że ta grupa zabytków o proweniencji scytyjskiej, w większości datowanych na VI w. p.n.e., nie musi (lub nawet nie może) wiązać się z kulturą wysocką. Łączenie jej schyłku z infiltracją scytyjską nie jest koncepcją nową. Przypomnijmy w tym miejscu cytującego badaczy ukraińskich Z. Bukowskiego (1966, s. 97): „...przybysze tej grupy [tj. zachodniopodolskiej - S.C.] podporządkowali sobie całkowicie osadnictwo wysockie, które w tym czasie przestaje istnieć jako samodzielna grupa kulturowa. Okres niepokojów, poprzedzających jej upadek, poświadcza występowanie w grobach wysockich grocików scytyjskich formy archaicznej typowych dla VII-VI w. p.n.e.".

Na południe od strefy zajętej przez kulturę wysocką, tj. w dorzeczu Dniestru, w późnej epoce brązu i w starszej części wczesnej epoki żelaza, należy wydzielić inną jednostkę kulturową. Mowa tu o kulturze holihradzkiej. Jej ekumena sięga środkowego dorzecza Dniestru i górnego Prutu (Otroŝenko 1998, s. 420-421; Czopek 2010b, s. 361). Trzeba przypomnieć, że w literaturze funkcjonują jej alternatywne 
case of bronze artifacts, especially those from hoards and loose finds, metallurgy being in the end the most characteristic feature of this group. Two hoards of gold artifacts from Mykhalkiv, recently re-studied (Bandrivs'kij, Krušel'nic'ka 2012), are perhaps the best known examples (from the end of the $19^{\text {th }} \mathrm{c}$.). Hillforts are the second most important characteristic (Krušel'nic'ka, Maleev 1990, pp. 123-125), which may impact further discussion. One example in point is the site of a fortified settlement Bykov near Drohobych (Czopek et al. 2016, pp. 451-552). Investigations on the Wisznia river (the present border between Poland and Ukraine) have also confirmed the presence of pottery (including grave goods) linked to this group (Czopek 2018, p. 173). A cultural divide has thus been traced between the Tarnobrzeg branch of Lusatian culture in the west and Holihrady culture in the east. It is more like a broad contact zone than a line, considering the growing emphasis in research on the "Tarnobrzeg-Holihrady" links (Trybała-Zawiślak 2019, pp. 56-70). Knowledge of Holihrady material is growing and there is a satisfactory development of research on many detailed characteristics of this culture group, e.g. settlement (Bandrivs'kij 2014, pp. 25-185). The oldest phases are defined by well-dated bronze hoards (Gruszka, Jargorów), which are referred to as the $\mathrm{BrD}-\mathrm{HaA1}$, i.e., $13^{\text {th }}-12^{\text {th }}$ centuries BC (Bandrivs'kij 2014, p. 156), whereas the youngest may be synchronous with the Kimmerian horizon, that is, the turn of the $9^{\text {th }}$ and the $8^{\text {th }}$ centuries BC, which is the date of the younger of the Mykhalkiv hoards (Bandrivs'kij, Krušel'nic'ka 2012, pp. 101-102). In a separate view, Bandrivskyi recently distinguished a Holihrady culture proper and a post-Holihrady stage identified with the Mykhalkiv group. The chronological boundary between them falls in the early $9^{\text {th }} \mathrm{c}$. BC, while the ultimate end is dated to the late $8^{\text {th }} \mathrm{C}$. BC (Bandrivs'kij 2014, pp. 156, 261), and even the $7^{\text {th }}$ c. BC (Krušel'nic'ka, Maleev 1990, p. 132).

\section{THE SCYTHIAN CULTURAL CIRCLE}

The Scythian cultural circle constituted an entirely new entity in eastern Europe, stretching over a vast area from the Danube and Dniester to left-bank Dnieper, all the way to the lower Don and Donets, and including enclaves in central Europe, in the basin of the Tysa and Danube, and in Transylvania (Melûkova 1989, map 5; Murzin 1998, pp. 40-43). This territory comprises two parts dependent on two different natural environments: the steppe ("main Scythia of the steppe", Melûkova 1989, pp. 51-59) and the forest-steppe (Petrenko 1989). The beginnings of this group in the eastern European steppe are connected to the coming of the first wave of nomads from the east, an event currently dated to the end of the $8^{\text {th }} \mathrm{c}$. BC (Alekseev 2003, pp. 15-37) or even earlier, about the middle of the century (Medvedskaâ 1992). The extensive territory under Scythian occupation or merely control (foremost the forest-steppe zone) presents a very similar material culture. The evident differences are conditioned primarily by earlier occupation of a given area, determining the emergence of smaller cultural units (groups). One of these groups, the Western Podolian, is traced to the Dniester in a small area on the fringes 
nazwy (synonimy w znaczeniu nie tylko językowym, ale też źródłowym), np. kultura trackiego halsztatu (tracki halsztat/Hallstatt), zespół (krąg, kultura) Gava-Holihrady (Krušel'nic'ka, Maleev 1990). Ta ostatnia nazwa podkreśla związki z Kotliną Karpacką, dobrze czytelne w przypadku znalezisk brązowych, w tym przede wszystkim pochodzących ze skarbów i znalezisk luźnych. Metalurgia jest bowiem najbardziej rozpoznawalną cechą tego ugrupowania. Jej najbardziej znanym (od końca XIX w.) przykładem są dwa skarby przedmiotów złotych z Michałkowa, które ostatnio doczekały się nowego opracowania (Bandrivs'kij, Krušel'nic'ka 2012). Druga ważna cecha to obecność grodzisk (Krušel'nic'ka, Maleev 1990, s. 123-125), co może mieć znaczenie dla późniejszych naszych rozważań. Przykładem takiego stanowiska jest Byków koło Drohobycza, gdzie zbadano ufortyfikowaną osadę (Czopek i in. 2016, s. 451-552). Badania nad Wisznią (czyli w strefie obecnego pogranicza polsko-ukraińskiego) również potwierdziły obecność materiałów ceramicznych (w tym także pochodzących z grobów), które można zaliczyć do tego ugrupowania (Czopek 2018, s. 173). Trzeba zatem stwierdzić, że zarysowała się rubież kulturowa między tarnobrzeską kulturą łużycką na zachodzie i strefą holihradzką na wschodzie. Nie ma ona jednak charakteru liniowego, a raczej szerszej strefy kontaktowej, bowiem coraz częściej akcentuje się związki „tarnobrzesko-holihradzkie” (Trybała-Zawiślak 2019, s. 56-70). Z satysfakcją należy odnotować coraz lepszą znajomość materiałów holihradzkich i stanu badań nad wieloma szczegółowymi zagadnieniami charakterystyki kulturowej, np. osadnictwa (Bandrivs'kij 2014, s. 25-185). Najstarszy etap tego ugrupowania wyznaczają dobrze datowane skarby brązowe (Gruszka, Jargorów), które można odnosić do BrD-HaA1, tj. XIII-XII w. p.n.e. (Bandrivs'kij 2014, s. 156), natomiast najmłodsze można synchronizować z horyzontem kimmeryjskim, tj. przełomem IX i VIII w. p.n.e. Tak bowiem należy określać pozycję młodszego ze skarbów michałkowskich (Bandrivs'kij, Krušel'nic’ka 2012, s. 101-102). Nieco odmienny pogląd przedstawił ostatnio M. Bandriwśkyj, który wyodrębnił właściwą kulturę holihradzką i etap postholihradzki utożsamiany z grupą michałkowską. Granica między nimi została wyznaczona na początek IX w. p.n.e., a jej koniec na schyłek VIII (Bandrivs'kij 2014, s. 156, 261), a nawet VII w. p.n.e. (Krušel'nic'ka, Maleev 1990, s. 132).

\section{SCYTYJSKI KRĄG KULTUROWY}

Wyraźnie nową jakość reprezentuje na terenie Europy wschodniej scytyjski krąg kulturowy, zajmujący bardzo rozległy obszar od Dunaju i Dniestru po lewobrzeże Dniepru aż do dolnego Donu i Dońca. Do tego należy dodać enklawy na terenie Europy środkowej - w dorzeczu Cisy i Dunaju oraz w Transylwanii (Melûkova 1989, mapa 5; Murzìn 1998, s. 40-43). W zasadniczym ujęciu obszar ten dzieli się na dwie części, pochodne odmiennych warunków środowiskowych - stepową („główna Scytia stepowa”, Melûkova 1989, s. 51-59) i lasostepową (Petrenko 1989). Początki tego ugrupowania łączone są z pojawieniem się na stepach wschodnioeuropejskich pierwszej fali nowych koczowników ze wschodu, co datuje się obec- 


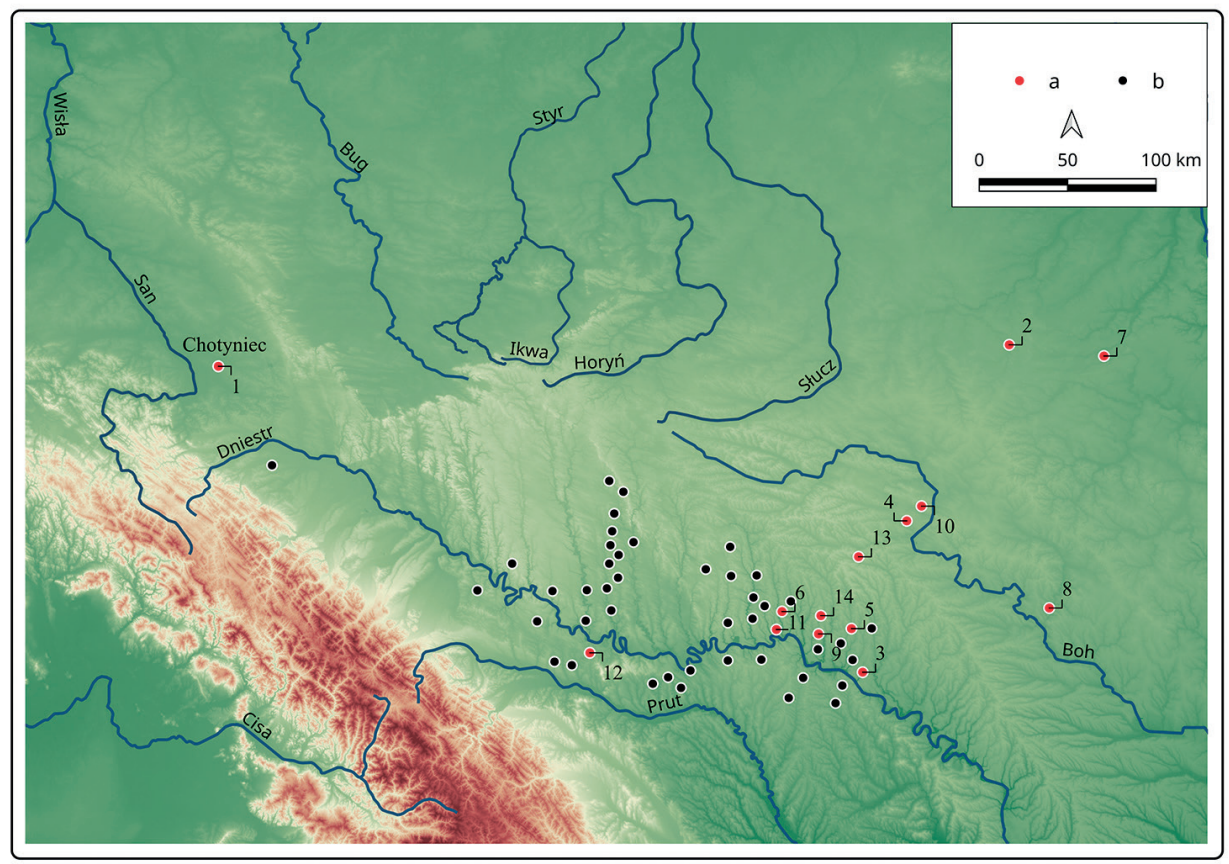

Ryc. 2. Mapa rozmieszczenia grodzisk (i domniemanych grodzisk) w zachodniej części leśnostepowej Scytii na tle stanowisk grupy zachodniopodolskiej

a - grodziska z okresu wczesnoscytyjskiego; b - stanowiska grupy zachodniopodolskiej; 1 - Chotyniec; 2 - Hrubske; 3 - Hryhorivka; 4 - Jakuszinci; 5 - Lomaziv; 6 - Matsiorsk; 7 - Mlynok; 8 - Nemyriv; 9 - Niżnijolczedaiv; 10 - Pereorky; 11 - Rudkivici; 12 - Ruchotyn; 13 - Severynivka.

Wg Ławniczaka i in. 2019; Smirnovej 2004, ryc. 1; Ėbertsa 2012, ryc. 1. Podkład mapy wg programów dostępnych w domenach publicznych do dowolnego wykorzystania: SRTM - Shuttle Radar Topography Mission (https://www2.jpl.nasa.gov/srtm/index.html; dostęp 1.04.2020) i Natural Earth (https://www.naturalearthdata.com; dostęp 1.04.2020)

Fig. 2. Map of the distribution of hillforts (and alleged hillforts) in the western forest-steppe part of Scythia compared to the location of sites of the Western Podolian group

$\mathrm{a}$ - hillforts from the early Scythian group; $\mathrm{b}$ - sites of the Western Podolian group; 1 - Chotyniec; 2 - Hrubske; 3 - Hryhorivka; 4 - Jakuszinci; 5 - Lomaziv; 6 - Matsiorsk; 7 - Mlynok; 8 - Nemyriv; 9 - Niżnijolczedaiv; 10 Pereorky; 11 - Rudkivici; 12 - Ruchotyn; 13 - Severynivka.

After Ławniczak et al. 2019; Smirnova 2004, Fig. 1; Èberts 2012, Fig. 1. Map base after programs in the public domain for unrestricted use: SRTM - Shuttle Radar Topography Mission (https://www2.jpl.nasa.gov/srtm/index.html; accessed 1.04.2020) and Natural Earth (https://www.naturalearthdata.com; accessed 1.04.2020)

of the forest-steppe zone. The group occupies the left bank of the Middle Dniester from the Strypa in the west to Murafa in the east, reaching the upper Prut in the south (Figs 1 and 2). From the start (distinguished first in Sulimirski 1936), it never raised any controversies regarding the date of its emergence and its membership in the Scythian cultural circle, even though some cultural differences were observed, e.g., cremation burials and some aspects of material culture, which were attributed 
nie na koniec VIII w. p.n.e. (Alekseev 2003, s. 15-37) lub nawet na wcześniejsze lata (około połowy) tego stulecia (Medvedskaâ 1992). Rozległe terytorium zajęte lub tylko podporządkowane przez Scytów (co można odnosić przede wszystkim do strefy lasostepu) cechuje bardzo podobna kultura materialna. Istnieją jednak oczywiste różnice, $\mathrm{w}$ tym przede wszystkim warunkowane przez wcześniejsze osadnictwo, które decydują o wyodrębnianiu mniejszych jednostek kulturowych (grup). Na szczególnie interesującym nas Naddniestrzu, stanowiącym zaledwie wycinek na północno-zachodniej rubieży strefy lasostepu, wydzielana jest grupa zachodniopodolska. Zajmuje ona głównie lewobrzeże środkowego Dniestru - od Strypy na zachodzie do Murafy na wschodzie, a na południu sięga górnego Prutu (ryc. 1 i 2). Od momentu jej wydzielenia (Sulimirski 1936) nie budziła większych kontrowersji w zakresie datowania, przynajmniej jeśli chodzi o jej początek oraz przynależność do scytyjskiego kręgu kulturowego. W tym drugim aspekcie akcentowane były wprawdzie odmienności kulturowe (np. obecność ciałopalenia, czy niektóre elementy kultury materialnej), które przypisywano oddziaływaniom trackiego kręgu kulturowego (kultura holihradzka), a nawet kulturze wysockiej (Sulimirski 1936, s. 33-39). Do tego należy dodać jeszcze grupę Nieporotowo kultury czarnoleskiej, obecną na środkowym Podniestrzu między X i VII w. p.n.e., a więc do czasu pojawienia się plemion scytyjskich (Krušel'nic'ka 1998, s. 179-189). W ostatnich latach stan znajomości źródeł tego ugrupowania wyraźnie się poprawił, co dotyczy wszystkich elementów zwykle branych pod uwagę jako charakteryzujące grupy czy kultury. Najlepiej znany jest obrządek pogrzebowy, a najsłabiej grodziska. Te ostatnie są szczególnie ważne w przypadku Chotyńca, mogą bowiem stanowić najbliższe analogie (ryc. 2). W grupie zachodniopodolskiej do niedawna nie akcentowano obecności grodzisk, tym samym charakteryzując osadnictwo jedynie na podstawie osad otwartych (Petrenko 1989, s. 73). W ostatnim czasie do interesującej nas jednostki zalicza się siedem grodzisk (Ławniczak, Ignaczak 2016; Ławniczak i in. 2019, s. 869-870). Żadne z nich nie było badane w co najmniej wstępnym zakresie, a w odniesieniu do niektórych z nich nie ma nawet danych dotyczących ich wielkości. Stan ich archeologicznego rozpoznania bardzo znacząco odbiega od "sąsiedniego" zgrupowania grodzisk nad górnym Bohem (np. Shelekhan i in. 2016). Sytuację komplikuje fakt, że niektóre z grodzisk mogą być wiązane także z okresem przedscytyjskim. Przykładem może być grodzisko rudkowieckie (Rudkivci - ryc. 2), na którym potwierdzono ślady starszego użytkowania i obecność wczesnych form grocików scytyjskich (Gucal 2000).

Jeśli chodzi o datowanie omawianej jednostki, należy podkreślić dużą zgodność opinii wszystkich badaczy. L. Kruszelnyćka (Krušel’nic'ka 1990, s. 156) umieszczała ją między połową VII i VI-V w. p.n.e., podobnie jak wielu innych archeologów (Petrenko 1989, s. 73; Smirnova 2004, s. 420-421; Mozolevskij 2013, s. 56-57). Późne, bo jeszcze $\mathrm{w} \mathrm{V}$ w. p.n.e., datowanie schyłku ugrupowania podkreślają także inni autorzy (Węgrzynowicz 2001, s. 89). Obecnie jednak końcowy etap tej grupy określa się nieco inaczej. Jan Chochorowski (2014, s. 21,25) dość precyzyjnie sytuuje grupę zachodniopodolską w ramach VII i 1 poł. VI w. p.n.e. Natomiast Janusz Kowalski (Kowalski-Biłokryłyy 2012), po wnikliwej analizie zespołów i zabytków 
to the impact of the Thracian circle (Holihrady culture) and even Vysocka culture (Sulimirski 1936, pp. 33-39). One should add here the Nieporotowo groups of Chornoliska culture, known to have thrived on the middle Dniester between the $10^{\text {th }}$ and the $7^{\text {th }}$ centuries BC, before the coming of the Scythian tribes (Krušel'nic'ka 1998, pp. 179-189). The body of evidence on all aspects usually taken into consideration when characterizing a group or culture has grown significantly in recent years. Burial rites are perhaps the best studied category, while very little is known about the strongholds. The latter are particularly important in the case of Chotyniec, because they would be the nearest parallel (Fig. 2). Until recently the Western Podolian group was characterized by open settlements alone (Petrenko 1989, p. 73), but now there are seven hillforts attributed to it (Ławniczak, Ignaczak 2016; Ławniczak et al. 2019, pp. 869-870). None have been excavated or even tested archaeologically, and for a few even a rudimentary estimate of size does not exist. They have not been surveyed to the extent that the "neighboring" group of strongholds on the upper Boh has been (e.g. Shelekhan et al. 2016). The situation is further complicated by the fact that some of these fortified settlements can be linked to a pre-Scythian occupation, e.g. the Rudkivci site (Fig. 2), where early forms of Scythian arrowheads coexisted with evidence of previous habitation (Gucal 2000).

Researchers are exceptionally in agreement on the dating of this unit: Krushelnytska (Krušel'nic'ka 1990, p. 156) placed it between the mid $7^{\text {th }}$ and $6^{\text {th }}-5^{\text {th }}$ centuries BC, an opinion shared by many other archaeologists (Petrenko 1989, p. 73; Smirnova 2004, pp. 420-421; Mozolevskij 2013, pp. 56-57). A late survival of the group, into the $5^{\text {th }}$ c. BC, was emphasized also by other researchers (Wegrzynowicz 2001, p. 89), but the current view is slightly different. Jan Chochorowski (2014, pp. 21, 25) gives fairly precise dates for the Western Podolian group within the $7^{\text {th }}$ and first half of the $6^{\text {th }}$ centuries BC, while Janusz Kowalski (Kowalski-Biłokryłyy 2012), having thoroughly analyzed artifacts and assemblages that have a precise chronology, was able to distinguish a small group of inventories dated to before the mid $7^{\text {th }} \mathrm{c}$. BC (phase I) and more numerous series of artifacts for the remaining phases: II (mid-to-thirdquarter of the $7^{\text {th }} \mathrm{c}$. BC) and III (end of $7^{\text {th }}-$ mid $6^{\text {th }}$ centuries BC). This proposition is largely in agreement with the later findings of Bandrivskyi (Bandrivskij 2014), whose revisions largely concern a slightly earlier dating of the beginnings (last quarter of the $8^{\text {th }} \mathrm{c}$. BC) as well as end of the group ( $1^{\text {st }}$ quarter of the $6^{\text {th }} \mathrm{c}$. BC). The largest number of sites comes from the second phase, which is dated to the $2^{\text {nd }}$ and $3^{\text {rd }}$ quarters of the $7^{\text {th }}$ c. BC (Bandrivs'kij 2014, pp. 306-355). Establishing the chronology of the Western Podolian group is key to understanding the cultural situation in the entire river basin of the middle and upper Dniester. Let it be assumed then that the group occupied the area from the turn of the $8^{\text {th }} / 7^{\text {th }}$ to the $2^{\text {nd }}$ half of the $6^{\text {th }} \mathrm{c}$. BC. The dating should be synchronized with part of the second phase and the entire third phase of the early Scythian culture (Medvedskaâ 1992) or with periods 1-4 in the general evolution of the Scythian cultural circle as established by Andrei Alekseev, covering the ages from the end of the $8^{\text {th }}$ to the turn of the $4^{\text {th }} / 3^{\text {rd }}$ c. BC (Alekseev 2003, p. 27).

The sudden disappearance of the Western Podolian group is considered to be the outcome of a population drive westward to the Great Hungarian Plain, where it 
o precyzyjnej chronologii, wydzielił dość niewielką grupę inwentarzy datowanych na okres przed połową VII w. p.n.e. (faza I) oraz liczniejsze serie przedmiotów z pozostałych faz - II (połowa-3 ćw. VII w.) i III (koniec VII - połowa VI w.). Ta propozycja jest $\mathrm{w}$ dużej mierze zgodna z późniejszymi ustaleniami M. Bandriwśkiego (Bandrivs'kij 2014). Wprowadzone przez niego korekty dotyczą nieco wcześniejszych datowań tak początku (ostatnia ćw. VIII w. p.n.e.), jak i końca (1 ćw. VI w. p.n.e.) tego ugrupowania. Największa liczba stanowisk jest odnoszona do środkowego, drugiego, etapu tej jednostki, datowanego na 2 i 3 ćw. VII w. p.n.e. (Bandrivs'kij 2014, s. 306-355). Ustalenie chronologii grupy zachodniopodolskiej jest kluczem do zrozumienia sytuacji kulturowej w całym dorzeczu środkowego i górnego Dniestru. Przyjmijmy zatem, że jest ona obecna od przełomu VIII/VII w. do 2 poł. VI w. p.n.e. Takie datowanie można synchronizować z częścią fazy drugiej i całą fazą trzecią kultury wczesnoscytyjskiej (Medvedskaâ 1992) lub okresami 1-4 w systemie rozwoju scytyjskiego kręgu kulturowego według Andreja Aleksejewa, obejmującymi czasy od końca VIII do przełomu IV/III w. p.n.e. (Alekseev 2003, s. 27).

Za przyczynę nagłego zaniku grupy zachodniopodolskiej uznaje się migrację ludności na zachód - do Wielkiej Niziny Węgierskiej, gdzie miała mieć decydujący wpływ na genezę kultury Vekerzug (Chochorowski 1985, s. 150-152; tenże 2014, s. 27-28). Inną możliwą interpretację zaproponował M. Bandriwśkyj, zwracając uwagę na odwrotny kierunek migracji znad Dniestru. Jego zdaniem, może tu chodzić o wymienioną przez Herodota wędrówkę Neurów do Budynów, która miała mieć miejsce na jedno pokolenie przed wojną Scytów z Persami (513-512 r. p.n.e.), a więc około połowy VI w. p.n.e. (Bandrivs'kij 2014, s. 398-403). Ta koncepcja wynika z odosobnionej interpretacji etnicznej społeczności grupy zachodniopolskiej, uznającej ją za część dużej prowincji zajmowanej w całej strefie prawobrzeżnego lasostepu przez ugrupowania scytyjsko-skolockie, w tym także Neurów. Jest to powrót do wcześniejszej tezy wysuwanej przez kilku badaczy (por. Melûkova 1989, s. 41), nieco inaczej teraz argumentowanej. Osłabienie jednoznacznych do tej pory związków ze światem scytyjskim ma wynikać $\mathrm{z}$ braku nie budzących wątpliwości, źródłowych przesłanek, które mogłyby wskazywać bezpośrednio na etniczno-językowy pierwiastek irański. Dla przeciwwagi wskażmy kategoryczne przypisania osadnictwa znad środkowego Dniestru do Wielkiej Scytii, w strefie lasostepu zamieszkiwanych przez rolnicze plemiona „Scytów-Oraczy” (np. Melûkova 1989, s. 45; Mozolevskij 2013, s. 138).

Jak już zaznaczono na wstępie, od czterech lat mamy do czynienia z nowym, bardzo istotnym zjawiskiem w dorzeczu Wiszni/Sanu, czyli aglomeracją chotyniecką. Pomimo, że jest ona ciągle na etapie badań (Czopek 2019), to możemy już mówić o wyjątkowym znaczeniu tego miejsca. Przede wszystkim odkryte na grodzisku w Chotyńcu i okolicznych osadach materiały nie znajdują kompleksowych (tj. pełnych co do ich zakresu) analogii. Ich wyjątkowy charakter, od grodziska z zolnikiem (jako miejscem kultowo-obrzędowym) po zbiór zabytków ruchomych, wskazuje bardzo wyraźnie na związki z leśnostepową strefą scytyjskiego kręgu kulturowego. W żadnej ze znanych do tej pory miejscowych lub bardzo bliskich terytorialnie kultur i grup cechy te wspólnie nie występują. Mowa tu o odmiennym systemie 
had a decisive impact on the emergence of Vekerzug culture (Chochorowski 1985, pp. 150-152; idem 2014, pp. 27-28). Bandrivskyi suggested a different interpretation, namely a return migration from the banks of the Dniester, citing Herodotus' story of the Neuri moving to the land of the Budini a generation before the war of the Persians with the Scythians (513-512 BC), that is, about the mid $6^{\text {th }} \mathrm{c}$. BC (Bandrivs'kij 2014, pp. 398-403). This is an isolated ethnic interpretation of a Western Podolian community considered as part of a large territory in the right-bank forest-steppe zone occupied by Scythian-Skolotoi groups, the Neuri included. It returns to earlier hypotheses put forward by different researchers (see Melûkova 1989 , p. 41), but with a slightly different reasoning behind it. The weakening of the so far unambiguous relationship with the Scythian world is supposed to derive from a lack of undoubted, source-based premises that could point directly to an ethniclinguistic Iranian element. As a counterbalance, one should indicate a categorical attribution of settlements from the middle Dniester River to Great Scythia which was occupied by the agricultural tribes of "Scythian Plowers" in the forest-steppe zone (e.g. Melûkova 1989, p. 45; Mozolevskij 2013, p. 138).

The Chotyniec agglomeration is a new component of the cultural landscape in the Wisznia/San river basin, introduced with the onset of research four years ago. The investigations are still ongoing (Czopek 2019), but the place appears to be of prime significance, the assemblage from the stronghold and surrounding sites finding no comprehensive (that is, full in their scope) parallels. The exceptional nature of the finds, from a stronghold with a ceremonial cult place (zolnik) to the assemblages of small finds, evinces close ties to the Scythian cultural circle from the forest-steppe zone. None of the local or nearby groups or cultures have jointly manifested these characteristics: a different settlement network, a rich material culture (including Greek imports, objects of gold, weapons and personal accessories, small clay figurines), different beliefs and presumably social structure (Czopek 2019; Trybała-Zawiślak 2019, pp. 264-282). These features specifically demonstrate the role and importance of the Chotyniec agglomeration for its neighbors.

Enough evidence has been collected already for a broader discussion of the chronology of the whole complex. The zolnik in the hillfort was completely investigated, yielding a very big assemblage of finds: 18,500 potsherds, more than 200 metal (bronze and iron) artifacts and 20 bone objects. Sherds of Greek wine amphorae from Ionian centers at Klazomenai and Lesbos (or related; Czopek 2019) can be dated quite precisely to the end of the $7^{\text {th }}$ and early $6^{\text {th }} \mathrm{c}$. BC, some even slightly later. Next the arrowheads for a Scythian type of arrow, made of bronze, iron and bone (Burghardt 2020), constituting a fairly compact set dated from the $2^{\text {nd }}$ half of the $7^{\text {th }}$ and the $1^{\text {st }}$ half of the $6^{\text {th }} \mathrm{c}$. BC. None of the arrowheads represented a later base type characterizing Scythian arms of the end of the $6^{\text {th }}$ and $5^{\text {th }}$ centuries BC (Czopek 2019, pp. 132-133, Fig. 15). Pins are another category of interest (AdamikProksa, Ocadryga-Tokarczyk 2020). The 21 examples, which differ in terms of their state of preservation, made of bronze, iron and bone, are not as homogeneous a set as the arrowheads because they include examples of much more extended chronology, including one that may even be of $4^{\text {th }} \mathrm{c}$. date (type with the head in the 
osadniczym, bogatym zestawie artefaktów składających się na kulturę materialną (w tym importy greckie i przedmioty złote, militaria i ozdoby, gliniana plastyka figuralna), odmiennych wierzeniach i zapewne strukturze społecznej (Czopek 2019; Trybała-Zawiślak 2019, s. 264-282). To właśnie one wskazują rangę i znaczenie aglomeracji chotynieckiej dla ościennych ugrupowań.

Odnośnie do datowania, to dysponujemy już dosyć dobrymi źródłami umożliwiającymi nawet nieco szersze dyskusje o chronologii całego zespołu. Podstawowych informacji dostarcza w tym zakresie całkowicie zbadany zolnik z grodziska w Chotyńcu. Pochodzi z niego bardzo liczna seria materiałów ruchomych - 18,5 tysiąca fragmentów naczyń, ponad 200 zabytków metalowych (brązowych i żelaznych) i 20 kościanych. Są wśród nich takie, które można dość precyzyjnie datować. W pierwszym rzędzie dotyczy to fragmentów greckich amfor na wino, które pochodzą z jońskich ośrodków garncarskich w Klazomenai i Lesbos (lub z nimi związanych; Czopek 2019) i mogą być odnoszone do końca VII i początku VI w. p.n.e., a niektóre fragmenty zapewne też i do okresu nieco późniejszego. W drugiej kolejności należy wymienić brązowe, żelazne i kościane grociki do strzał typu scytyjskiego (Burghardt 2020). Jest to dość zwarty zbiór, który można datować na 2 poł. VII i 1 poł. VI w. p.n.e. Ważne jest, że wśród serii kilkudziesięciu przedmiotów tego typu nie odnotowano egzemplarzy późniejszych, tzw. bazowych, charakteryzujących militaria scytyjskie z końca VI i V w. p.n.e. (Czopek 2019, s. 132-133, ryc. 15). Kolejną kategorią zabytków są szpile (Adamik-Proksa, Ocadryga-Tokarczyk 2020). Znaleziono 21 egzemplarzy, w różnym stanie zachowania, wykonanych z brązu, żelaza i kości. Zbiór ten nie jest już tak jednorodny jak w przypadku grocików, bowiem występują okazy o znacznie dłuższej chronologii, a zidentyfikowano też szpilę, którą można odnosić nawet do IV w. p.n.e. (typ z główką w postaci faliście wygiętego pręta). Trzeba jednak zaznaczyć, że znaczną część tego zbioru - przede wszystkim zabytki o główkach gwoździowatych (grzybkowatych) - można umieszczać w końcu VII i w VI w. (Czopek 2019, s. 133, ryc. 17; Adamik-Proksa, Ocadryga-Tokarczyk 2020). Istnieją jeszcze przesłanki, aby do wyrobów datujących zaliczyć fragmenty dużych naczyń wazowatych o czarnych, gładkich powierzchniach, znanych np. ze stanowisk grupy zachodniopodolskiej (a tym samym datowane tak jak ta grupa na VII-VI w. p.n.e.), które uważa się za wcześniejsze reminiscencje holihradzkie lub czarnoleskie.

Seria dat radiowęglowych z zolnika (Trybała-Zawiślak 2019, s. 286-290; Czopek, Krąpiec 2020) dostarcza kolejnych, interesujących wniosków. Część z nich $(2520 \pm 70$ i $2470 \pm 70 \mathrm{BP})$ potwierdza jego funkcjonowanie w VII-VI w. p.n.e., będąc w zgodzie z chronologią przywołanych wcześniej i dobrze datowanych przedmiotów. Jednakże odnotować należy także oznaczenia dziewiątowieczne $(2750 \pm 90$, $2679 \pm 35 \mathrm{BP}$ ), które mogą wskazywać na wcześniejszą chronologię grodziska w Chotyńcu, a z pewnością starszą niż założenie zolnika. Ważne jest, że z sąsiedniej, oddalonej o około $200 \mathrm{~m}$, osady w Hruszowicach, stan. 2, uzyskano podobną datę (2680 \pm 40 BP; Krąpiec 2014, s. 167). Materiały ruchome z tego stanowiska są identyczne jak znalezione na grodzisku.

Zastanawia też grupa dat najmłodszych (między $2380 \pm 80$ a $2310 \pm 70 \mathrm{BP}$ ) bardzo jednoznacznie wskazujących na użytkowanie zolnika jeszcze w V-IV w. p.n.e. 
shape of a wave-shaped rod). The bulk of the set, primarily the nail-shaped pins, can be placed in the end of the $7^{\text {th }}$ and the $6^{\text {th }}$ c. BC (Czopek 2019, p. 133, Fig. 17; Adamik-Proksa, Ocadryga-Tokarczyk 2020). There are premises also to consider large cylindrical vases with smooth burnished surfaces as dating elements. Such vessels are known from sites of the Western Podolian group (and dated like these sites to the $7^{\text {th }}-6^{\text {th }}$ centuries $\mathrm{BC}$ ) and are considered as reminiscences of earlier Holihrady or Chornoliska examples.

A series of radiocarbon dates from the zolnik (Trybała-Zawiślak 2019, pp. 286290; Czopek, Krąpiec 2020) contributed further interesting conclusions. Some of these dates $(2520 \pm 70$ and $2470 \pm 70 \mathrm{BP})$ confirm the functioning of the ceremonial center in the $7^{\text {th }}-6^{\text {th }}$ centuries $B C$, which is in agreement with the chronology of the well-dated artifacts described. However, there is also a $9^{\text {th }}$ c. date $(2750 \pm 90$, $2679 \pm 35 \mathrm{BP}$ ), which could point to an earlier chronology of the hillfort in Chotyniec, certainly earlier than the founding of the zolnik. More importantly, a similar date (2680 \pm 40 BP; Krąpiec 2014, p. 167) was obtained from a neighboring settlement, site 2, at Hruszowice, about $200 \mathrm{~m}$ away. The small finds from the site are identical with finds from the hillfort.

The group of youngest dates, between $2380 \pm 80$ and $2310 \pm 70 \mathrm{BP}$, indicates beyond doubt the use of the cult place in the $5^{\text {th }}$ and $4^{\text {th }}$ centuries BC. These determinations are very probable and further confirmed by the stratigraphic sequence (vestiges of the youngest phase traced on the fringes of the feature), but the youngest radiocarbon date $(2280 \pm 100 \mathrm{BP})$, pointing even to the $3^{\text {rd }} \mathrm{c}$. BC, is not very credible, an assessment confirmed by knowledge of the general cultural situation in the region. The functioning of the zolnik in light of the radiocarbon dates can be estimated at about 300 years. More importantly, it reaches beyond the mid- $6^{\text {th }} \mathrm{c}$. BC, thus confirming the presence of a culture of the "Scythian" type already after the disappearance of the Western Podolian group from the middle Dniester. Without determining the exact nature of the relation between the Chotyniec region and the Western Podolian group proper, we can surely say that both groups emerged at the same time (in the $7^{\text {th }} \mathrm{c}$. BC), but that the settlement in the Chotyniec region lasted longer.

\section{THE LEZHNICA AND CHEREPIN-LAGODIV GROUPS}

There are two other groups from the early Iron Age that are important to the present discussion: the Lezhnica and the Cherepin-Lagodiv groups (Fig. 1). Their emergence may be linked to the transformation initiated by the coming of the Scythian cultural circle to the region. The territory attributed to the Lezhnica group covers an area of approximately $7000-8000 \mathrm{~km}^{2}$ and its sites are located in the interfluve of the Bug and Styr rivers, north of the range of the Cherepin-Lagodiv group and reaching the sources of the Stokhid and Turija rivers. The distinctly outlined border on the Bug indicates that the full range westward is not known. Krushelnytska clearly emphasized the formal ties between materials of this group and Lusatian 
O ile $\mathrm{w}$ odniesieniu do tych oznaczeń jest to prawdopodobne, a także potwierdzone w świetle stwierdzonej stratygrafii (najmłodsza faza użytkowa uchwycona tylko szczątkowo na obrzeżach tego obiektu), o tyle najmłodsza data radiowęglowa $(2280 \pm 100$ BP), mogąca wskazywać nawet na III w. p.n.e., jest mało wiarygodna. Potwierdza to znajomość ogólnej sytuacji kulturowej w całym regionie. Tak więc funkcjonowanie zolnika w świetle dat radiowęglowych można szacować na około 300 lat. Ważne jest przy tym, że wykracza ono poza połowę VI w. p.n.e., a więc potwierdza obecność kultury w typie „scytyjskim” już po zaniku grupy zachodniopodolskiej nad środkowym Dniestrem. Nie rozstrzygając w tej chwili relacji między regionem chotynieckim a właściwą grupą zachodniopodolską, z całą pewnością można stwierdzić, że pojawiają się one w tym samym czasie (VII w. p.n.e.), ale osadnictwo w okolicach Chotyńca trwa dłużej.

\section{GRUPY LEŻNICKA I CZEREPIŃSKO-ŁAGODOWSKA}

Kolejnym etapem naszego wnioskowania jest przedstawienie dwóch jednostek grup leżnickiej i czerepińsko-łagodowskiej (ryc. 1), które są odnoszone do wczesnej epoki żelaza, a ich powstanie można wiązać ze zmianami wywołanymi pojawieniem się scytyjskiego kręgu kulturowego. Terytorium przypisywane do grupy leżnickiej obejmuje obszar około 7-8 tys. $\mathrm{km}^{2}$, a jej stanowiska rozlokowane są w międzyrzeczu Bugu i Styru, na północ od granicy zasięgu grupy czerepińsko-łagodowskiej i dochodzą do źródeł Stochidu (Stochodu) i Turii. Uderzająca jest bardzo ostro zarysowana granica na Bugu, co wyraźnie wskazuje na jej niepełny zasięg w kierunku zachodnim. L. Kruszelnyćka w swych obydwu pracach bardzo wyraźnie akcentuje formalne związki materiałów tej grupy z kulturą łużycką, traktując ją jako tę, która zastąpiła łużyckie stanowiska (Krušel'nic'ka 1976; 1993). Zmiana ta miała się dokonać we wczesnej epoce żelaza, ze wskazaniem na VII w. p.n.e. Znamienne jest, że autorka użyła w tym przypadku trybu przypuszczającego, pisząc wyraźnie o przypuszczalnej chronologii, co było uzasadnione brakiem dobrych wyznaczników chronologicznych w wyrywkowo znanych materiałach. Na dodatek, pojawia się tam stwierdzenie o synchronizacji tego procesu z początkiem wczesnej epoki żelaza. Rubież chronologiczna epok brązu i żelaza powinna być teraz odnoszona do przełomu IX/VIII w. (Trachsel 2004; Czopek 2010a, s. 244). Czy zatem należy przyjąć taką korektę w datowaniu grupy leżnickiej? Trzeba odnotować, że L. Kruszelnyćka dość istotnie zmieniła swoje wcześniejsze poglądy, nie tylko w kwestii chronologii. Brak dobrze zdefiniowanych cech kulturowych jest powodem często używanego terminu o wpływach zewnętrznych czy to wcześniejszych (kultura łużycka, ewentualnie wysocka), czy synchronicznych (krąg Gava-Holihrady, elementy przedscytyjskie i scytyjskie). Stąd też pojawia się teza o szerszym niż pierwotnie przyjmowano datowaniu grupy leżnickiej, sięgającym jeszcze co najmniej schyłku epoki brązu, a na wczesną epokę żelaza, i to nie najwcześniejszy jej okres, miał przypadać tylko jej młodszy etap, datowany od VII w. p.n.e. (Krušel'nic'ka 1993, s. 158-157). Zgodzić się wypada z poglądem, że grupa leżnicka może być traktowana jako bardzo synkre- 
culture, treating the former as the one which superseded the latter in the early Iron Age, more specifically in the $7^{\text {th }}$ C. BC (Krušel'nic'ka 1976; 1993). She expressed her views in the conditional, which was justified by the lack of good chronological indicators in the random materials that were available. She also synchronized the process with the beginning of the early Iron Age. The division between the Bronze and Iron Ages should now be referred to as the $9^{\text {th }} / 8^{\text {th }}$ centuries BC (Trachsel 2004; Czopek 2010a, p. 244). Should one accept such a revision of the dating of the Lezhnica group? Krushelnytska actually changed her earlier views quite substantially, not only on the issue of chronology. Having no satisfactorily defined cultural characteristics on hand, researchers frequently turn to external influences, whether earlier (Lusatian culture, possibly Vysocka culture) or synchronous (GavaHolihrady circle, pre-Scythian and Scythian elements). Hence the idea of a broader than previously accepted dating of the Lezhnica group, the onset being at least in the terminal Bronze Age and only the younger phase, dated to the $7^{\text {th }} \mathrm{c}$. BC, being in the Iron Age (Krušel'nic'ka 1993, pp. 158-157). One agrees with the view that the Lezhnica group should be treated as a very syncretic (that is, heterogeneous) cultural phenomenon on the border of at least two cultural zones. However, one wonders whether this is enough to distinguish a cultural unit for which there are no unequivocal markers, no precise chronology and only roughly traced territory based on random source material.

The example of finds from the vicinity of the locality of Khrynniki on the banks of the Styr river (so-called Khrinniki water reservoir) is a telling case in point. The first publication in 1993 assigned the initial finds to Lezhnica group pottery (Krušel'nic'ka 1993, pp. 151-153, Fig. 82), mentioning parallels from other sites, but showing only those of evident Holihrady provenance. Denis Kozak's monograph from 2012 brought together a sizable set of sources from different periods, including early Iron Age settlement at the Shankiv Jar site (Khrynniki) (Kozak 2012, pp. 7-60). The pottery (Figs 3 and 4), represented by pot-shaped vessels with pierced holes under the rim and high plastic bands, bowls with incurved rims and pierced holes (or pseudo-holes not fully pierced) from inside at the point of maximum body diameter, and disk-like dishes, all have parallels, primarily in the Scythian forest-steppe zone. Three-winged arrowheads, representing the so-called base group without a distinguished sleeve, are a dating element (they are dated to the end of the $6^{\text {th }}$ and the $5^{\text {th }}$ centuries BC). Kozak's analysis emphasized primarily the ties with Lusatian culture, using it as grounds for distinguishing two occupation horizons: $\mathrm{HaB} 1-\mathrm{HaB} 2 / \mathrm{B} 3$ and HaB3-HaD1 (Kozak 2012, p. 34). This corresponds to at least 300 years of occupation, something that has not been confirmed by any study of the spatial layout of the settlement. The cited "Lusatian" parallels are also doubtful as a base for a HaB dating. Parallels from the zone of the "Scythian" forest-steppe, that are the most significant from an informative point of view, are merely a backdrop in this instance. Khrinniki lie on the eastern border of the Lezhnica group, hence parallels among the more expressive and distinctive finds are hardly surprising. It is worth emphasizing that this material is also linked to the forest-steppe world. Kozak's conclusion concerns a "new cultural community encompassing part of the 
tyczne (tj. niejednorodne) zjawisko kulturowe na rubieżach co najmniej dwóch stref kulturowych. Niemniej jednak rodzi się pytanie, czy to jest wystarczające kryterium do wydzielenia określonej jednostki kulturowej, w odniesieniu do której nie dysponujemy jednoznacznymi wyznacznikami, precyzyjną chronologią i tylko z grubsza zarysowanym terytorium na podstawie wyrywkowych materiałów?

Bardzo znamienny jest tutaj przykład znalezisk z badań nad Styrem (tzw. Chrinnickie wodoschowiszcze), w okolicach miejscowości Chrynniki. W 1993 r. opublikowano pierwsze materiały, umieszczając je wśród ceramiki leżnickiej (Krušel'nic'ka 1993, s. 151-153, ryc. 82). Wprawdzie autorka mówi o analogiach z innych stanowisk, ale eksponuje jedynie te o ewidentnej holihradzkiej proweniencji. W $2012 \mathrm{r}$. ukazała się monografia Denisa Kozaka, w której opublikowano pokaźny zestaw źródeł z wielu okresów, w tym z osady na stanowisku Szankiw Jar (Chrynniki) z wczesnej epoki żelaza (Kozak 2012, s. 7-60). Ceramika (ryc. 3 i 4), reprezentowana przez okazy garnkowate $\mathrm{z}$ otworkami pod krawędzią, plastycznymi, wysokimi listwami, misy z brzegami zagiętymi do wnętrza naczynia i otworkami (lub pseudootworkami nie do końca przekłutymi) wykonanymi od wewnątrz na największej wydętości brzuśca oraz talerze-placki, wskazuje wiele analogii, w tym przede wszystkim w strefie scytyjskiego lasostepu. Elementem datującym jest trójskrzydły grocik do strzały, reprezentujący grupę tzw. bazowych, bez wydzielonej tulei, który pochodzi z końca VI i V w. p.n.e. Przeprowadzona w publikacji analiza akcentuje przede wszystkim związki z kulturą łużycką. Na tej podstawie mowa jest o wydzieleniu na osadzie dwóch horyzontów, przypadających na HaB1-HaB2/B3 oraz HaB3-HaD1 (Kozak 2012, s. 34). Musiałaby ona funkcjonować przez co najmniej 300 lat, a tego nie potwierdzono żadną analizą zagospodarowania przestrzeni osady. Cytowane analogie „łużyckie” także budzą wątpliwości jako podstawa datowania na HaB. Najbardziej nośne informacyjnie analogie ze strefy „scytyjskiego” lasostepu są tu jedynie tłem. Chrynniki leżą na wschodniej granicy grupy leżnickiej, stąd nie mogą dziwić analogie przywoływane spośród części jej bardziej wyrazistych i dystynktywnych materiałów. Warto podkreślić, że tam też można je uznać za związane ze światem lasostepu. W konkluzji rozważań o tych materiałach jest formułowany wniosek o istnieniu „nowej kulturowej wspólnoty, jaka obejmuje część tarnobrzeskiej grupy kultury łużyckiej, łużycką kulturę z dorzecza Bugu, zachodni Wołyń i część Przykarpacia" (Kozak 2012, s. 34-35). W jej obrębie mogły istnieć jakieś lokalne ugrupowania - np. „wołyńska kultura wczesnej epoki żelaza”, dla której reprezentatywne są właśnie materiały typu Chrynniki. Wymieniona tu tarnobrzeska kultura łużycka w swej najmłodszej fazie (Moskwa 1976, s. 97-104; tenże 1982, s. 311-314) rzeczywiście charakteryzuje się podobnymi cechami. W odniesieniu do niej można także wykazać bardziej dogłębne przemiany - np. w obrządku pogrzebowym czy osadnictwie (Trybała-Zawiślak 2019, s. 96-182).

Stanowiska przypisywane do grupy czerepińsko-łagodowskiej rozciągają się między rzekami Dniestr i Stryj na południu, górnym Bugiem i Połtwą na północy oraz Złotą Lipą na wschodzie, a na zachodzie sięgają źródeł i górnego biegu Szkła (ryc. 1). W przybliżeniu jest to obszar liczący $12-13$ tys. $\mathrm{km}^{2}$. Podobnie jak w przypadku grupy leżnickiej, podkreślany jest synkretyczny charakter i tej jed- 

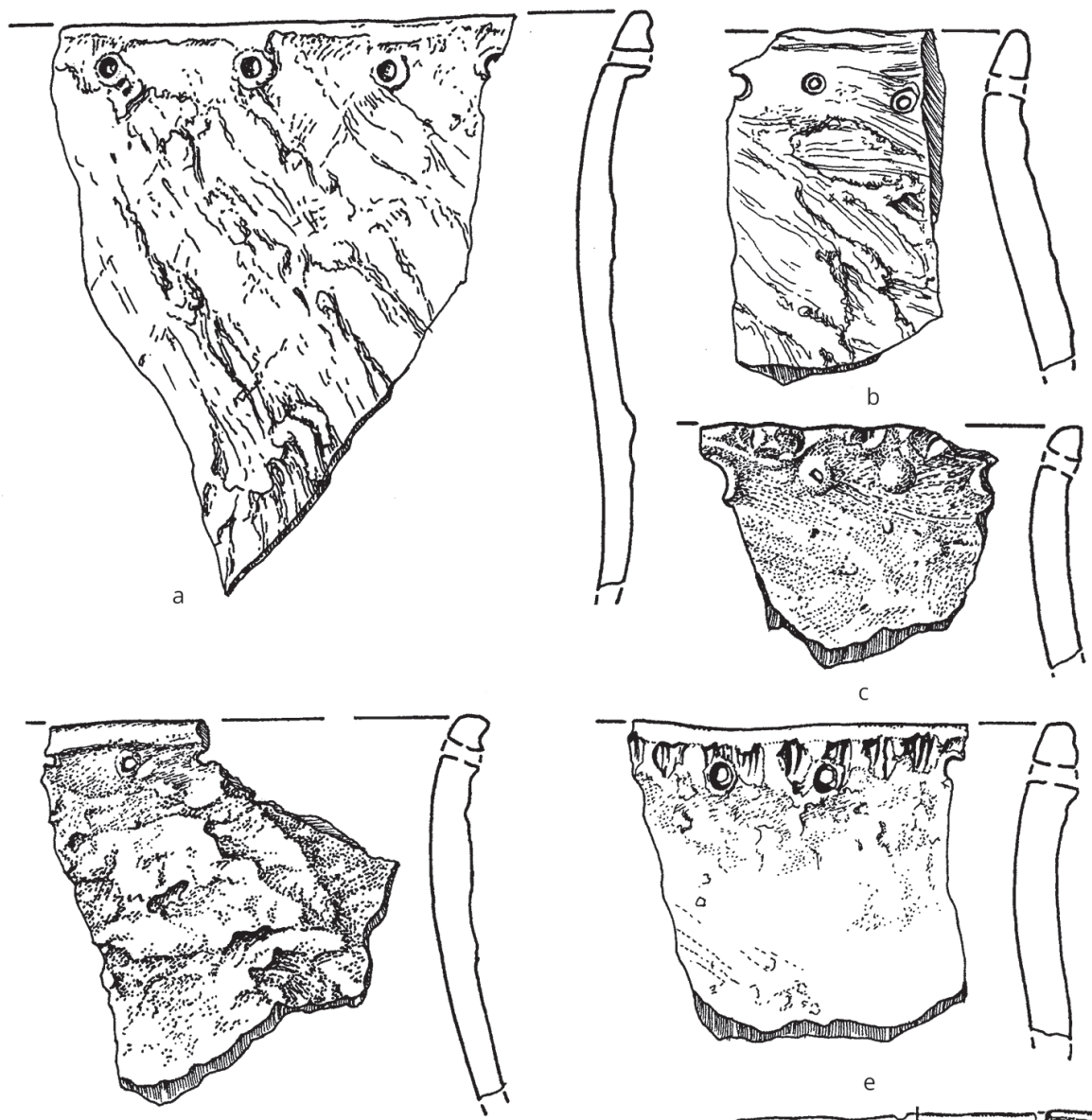

C

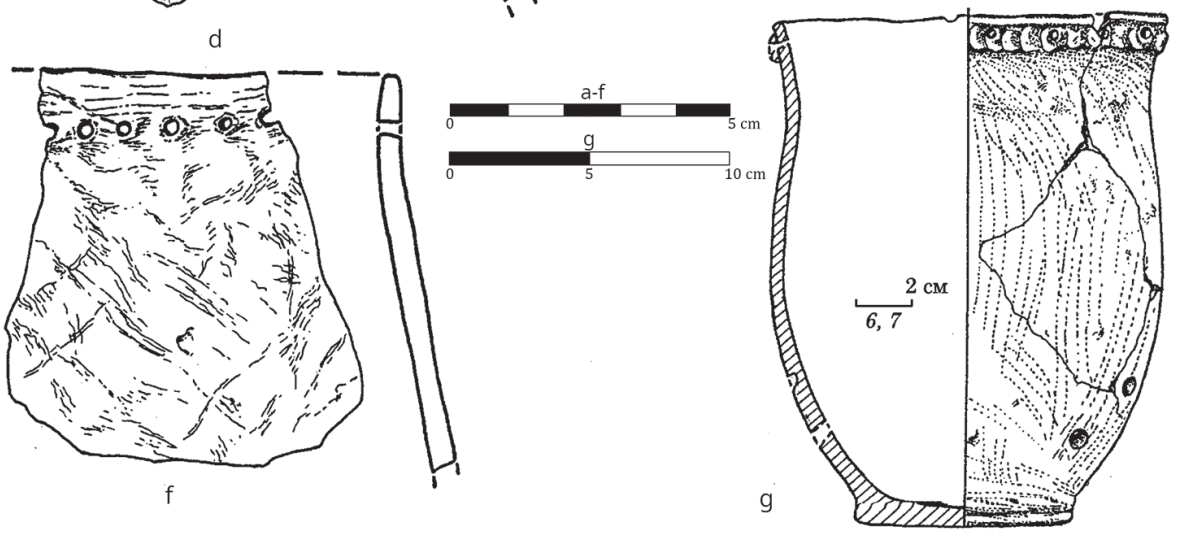

Ryc. 3. „Chrinnickie wodoschowiszcze”, stan. Szankiw Jar. Wybór ceramiki - naczynia garnkowate. Wg Kozaka 2012, tabl. 2:3, 6, 7; 12:3; 13:1, 2, 3

Fig. 3. "Khrinnicke vodoskhovyshche", Shankiv Jar site. Selection of pottery - pot-shaped vessels. After Kozak 2012, Pls 2:3, 6, 7; 12:3; 13:1, 2, 3 


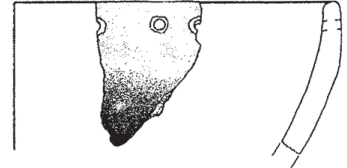

a

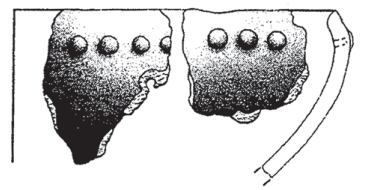

$c$

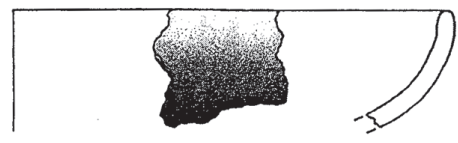

e

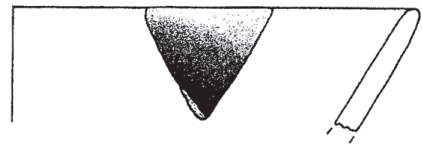

g

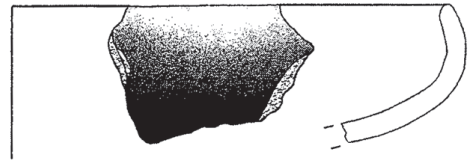

b

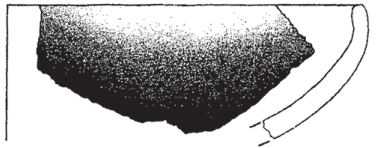

d

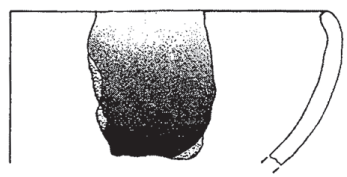

f

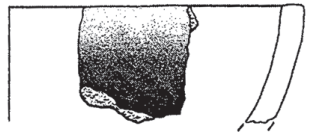

h

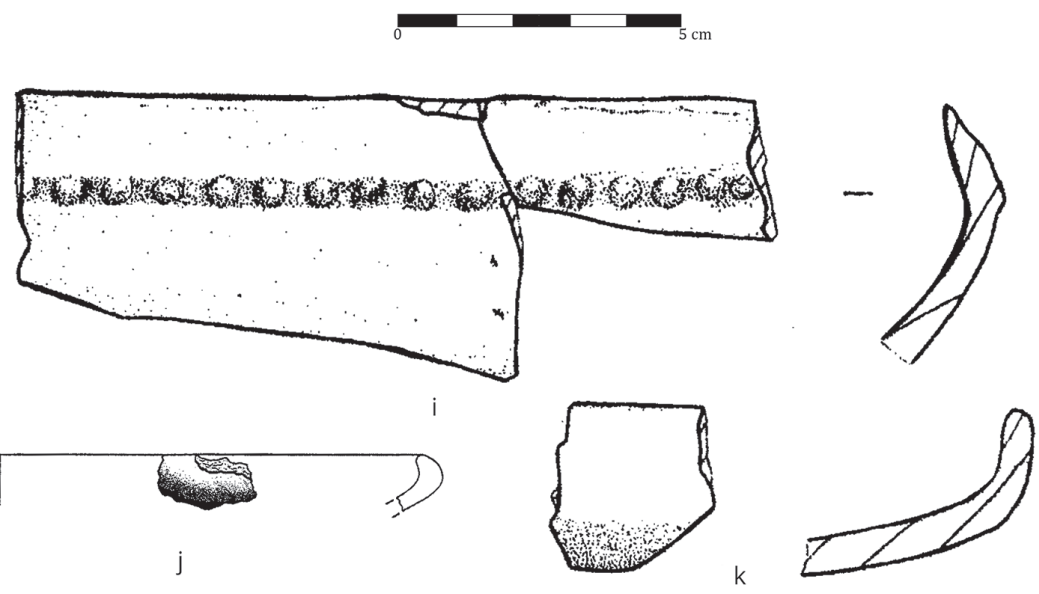

Ryc. 4. „Chrinnickie wodoschowiszcze”, stan. Szankiw Jar. Wybór ceramiki - misy.

Wg Kozaka 2012, tabl. 10:2, 3; 19:1-9

Fig. 4. "Khrinnicke vodoskhovyshche", Shankiv Jar site. Selection of pottery - bowls.

After Kozak 2012, Pls 10:2, 3; 19:1-9 
Tarnobrzeg group of Lusatian culture, the Lusatian culture in the basin of the Bug river, western Volhynia and a part of the Circumcarpathia" (Kozak 2012, pp. 34-35). Local groups could have existed within this larger frame, such as the "Volhynian culture of the Early Iron Age" represented by material of the Khrinniki type. The abovementioned Tarnobrzeg group of Lusatian culture in its youngest phase (Moskwa 1976, pp. 97-104; idem 1982, pp. 311-314) has similar characteristics. Sweeping changes in burial customs and settlement, for example, may be pointed out with regard to this unit as well (Trybała-Zawiślak 2019, pp. 96-182).

Sites attributed to the Cherepin-Lagodiv group are located between the rivers Dnieper and Stryi in the south, the upper Bug and Poltva in the north, the Golden Lipa in the east and the sources and upper run of the Schklo in the west (Fig. 1). This is a territory covering $12,000-13,000 \mathrm{~km}^{2}$. The syncretic nature of this unit is stressed in much the same way as in the case of the Lezhnica group. Elements of late Vysocka culture, Holihrady culture and early Scythian culture are described, evoking the group as "the westernmost part of the Western Podolia cultural group of the farming tribes" (Krušel'nic'ka 1976, pp. 104-105). At the time that it was distinguished, it was dated to the $2^{\text {nd }}$ half of the $7^{\text {th }}$ through the beginning of the $5^{\text {th }} \mathrm{c}$. BC (Krušel'nic'ka 1976, p. 103) and the chronological determinations remained more or less unchanged also in later studies (Krušel'nic'ka 1990, pp. 151; eadem 1993, pp. 238-239). Unlike the Lezhnica group, there are in this case broad opportunities for synchronizing with the Scythian cultural circle, especially the oldest series of arrowheads (including rhomboid ones), nail-like earrings and pins that the researcher erroneously attributed to Vysocka culture. An interesting idea (from the point of view of potential relations between the Scythian world and neighboring territories) concerns the late (terminal) Cherepin-Lagodiv group. Krushelnytska suggested either a cataclysm and depopulation or a peaceful continued functioning with a changed general appearance incorporating stronger "Scythian" connotations (Krušel'nic'ka 1993, p. 239).

The sources of this group are very differentiated. Larger series of material come, notably, from settlement sites and practically nothing is known about the burial customs except that it was cremation. The 15 burial features discovered at the Lagodowo site were practically devoid of inventory and bone material, and the only characteristic feature were the stone structures. Of singular importance in this context are the three cremations from the Berekhove 2 site in the Mostyska district (Czopek et al. 2018, pp. 308-331). Grave No. 1 in particular (Fig. 5) yielded an inventory of a few objects of bronze, including two arrowheads of Scythian provenance, of which one may be dated even to the $7^{\text {th }} \mathrm{c}$. The remaining artifacts, a pin with a looped head, a small pin with spherical head, multi-spiral bracelet and a looped circle also find parallels among personal accessories identified as Scythian (Petrenko 1978, Pls 9; 12; 13; 44; 51), although these forms are fairly common also on other cultures. In territorial terms, the site falls in the western part (even on the fringes) of the Cherepin-Lagodiv group. For the present discussion it is important to note the presence of pottery in the inventories. Its style and technology (fabric tempered with grog) bring to mind vessels typical of the forest-steppe variant of 
nostki. Mówi się o obecności elementów późnowysockich, holihradzkich i wczesnoscytyjskich, traktując ją jako „najdalej na zachód wysuniętą część zachodniopodolskiej grupy kulturowej plemion rolniczych" (Krušel'nic'ka 1976, s. 104-105). $\mathrm{W}$ momencie jej wydzielenia została wydatowana na 2 poł. VII do początku V w. p.n.e. (Krušel'nic'ka 1976, s. 103). Podobne ustalenia znajdziemy także w późniejszych pracach (Krušel'nic'ka 1990, s. 151; taż 1993, s. 238-239). W odróżnieniu od grupy leżnickiej, mamy w tym przypadku sporo możliwości synchronizowania ze scytyjskim kręgiem kulturowym. Takie możliwości dają przede wszystkim grociki najstarszych serii (w tym romboidalne), zausznice gwoździowate i szpile, błędnie odnoszone przez tę badaczkę do kultury wysockiej. Interesująca hipoteza (z punktu widzenia ewentualnych relacji świata scytyjskiego z sąsiednimi terenami) dotyczy końca (schyłku) grupy czerepińsko-łagodowskiej. L. Kruszelnyćka sugerowała dwie możliwości: kataklizm i wyludnienie lub spokojne funkcjonowanie w ramach zmienionego oblicza o silniejszych konotacjach „scytyjskich” (Krušel'nic'ka 1993, s. 239).

Źródła omawianej grupy są bardzo zróżnicowane. Trzeba zwrócić uwagę, że większe serie materiałów pochodzą wyłącznie ze stanowisk osadowych. Obrządek pogrzebowy jest prawie nierozpoznany, poza ogólnym stwierdzeniem o występowaniu kremacji. Na stanowisku w Łagodowie odkryto wprawdzie 15 obiektów grobowych, ale prawie pozbawionych inwentarza i materiału kostnego. Jedyną charakteryzującą je cechą były konstrukcje kamienne. Bardzo ważne w tym kontekście wydają się być trzy groby ciałopalne ze stanowiska Berehowe 2, raj. mościski (Czopek i in. 2018, s. 308-331). Szczególnie istotny jest grób nr 1 (ryc. 5) z racji obecności w inwentarzu kilku przedmiotów z brązu, w tym dwóch grocików o scytyjskiej proweniencji, z których jeden może być datowany nawet na VII w. p.n.e. Pozostałe zabytki - szpila z główką zwiniętą w uszko, mała szpila z główką kulistą, wielozwojowa bransoleta i kółko-skręt także mają analogie wśród ozdób uznawanych za scytyjskie (Petrenko 1978, tabl. 9; 12; 13; 44; 51), są to jednak okazy o formach znanych dość powszechnie także z innych kultur. Stanowisko to terytorialnie należy do zachodniej części (a nawet rubieży) grupy czerepińsko-łagodowskiej. Z punktu widzenia niniejszych rozważań należy podkreślić obecność w inwentarzach ceramiki, której stylistyka i technologia (obecność szamotu w masie ceramicznej) nawiązują do naczyń z leśnostepowego wariantu scytyjskiego kręgu kulturowego (Gejko 2011). Chodzi tu przede wszystkim o garnki z otworkami (nie zawsze do końca przekłutymi) i wysoko umieszczonymi listwami plastycznymi (ryc. 6) oraz o niektóre typy mis.

Grupy leżnicka i czerepińsko-łagodowska w świetle dotychczasowych ustaleń, zajmują sąsiednie w stosunku do siebie terytoria i są najdalej na zachód wysuniętymi ugrupowaniami kulturowymi wczesnej epoki żelaza wydzielanymi na obszarze Ukrainy. Wielkościowo terytoria obydwu grup nie odbiegają od niektórych jednostek łużyckiego kręgu kulturowego, są jednak wyraźnie mniejsze od wielu ugrupowań wschodnioeuropejskich, które już od wczesnej epoki brązu zajmują duże ekumeny. Istotna może być obserwacja, że te duże jednostki wykazują preferencje do równoleżnikowych układów, respektujących warunki naturalne Europy wschodniej - step, lasostep, las. Dotyczy to np. takich kultur jak: zrębowa, bie- 

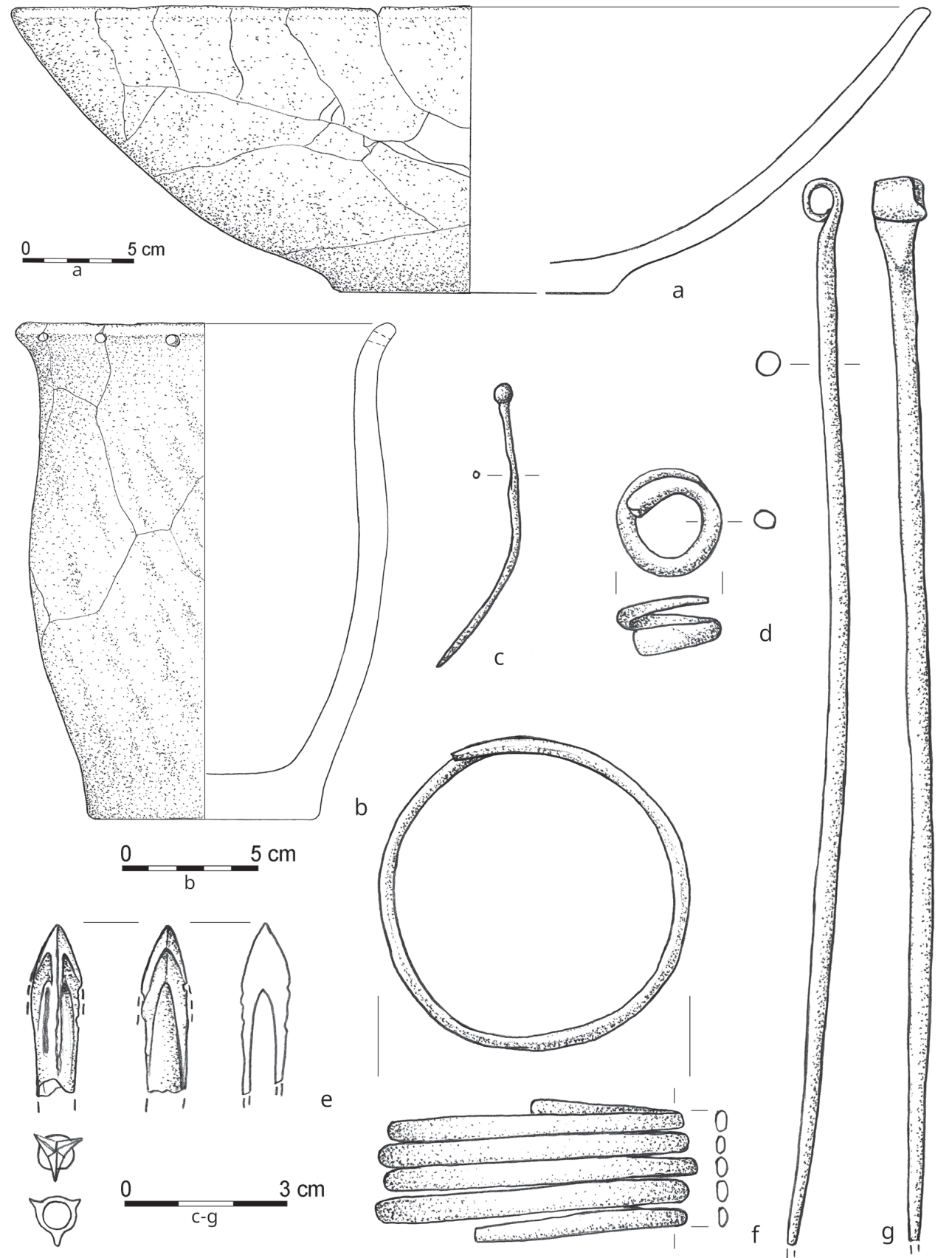

a

C

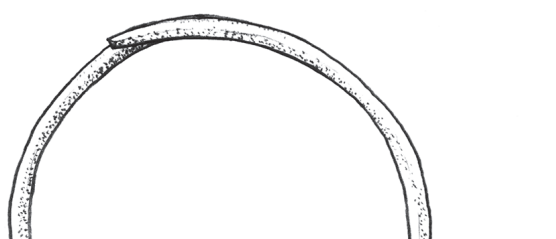

Ryc. 5. Berehowe, raj. mościski, stan. 2. Inwentarz grobu ciałopalnego nr 1.

Wg Czopka i in. 2018, ryc. 9.70

Fig. 5. Berekhove, Mostyska district, site 2. Grave goods from cremation burial No. 1.

After Czopek et al. 2018, Fig. 9.70 


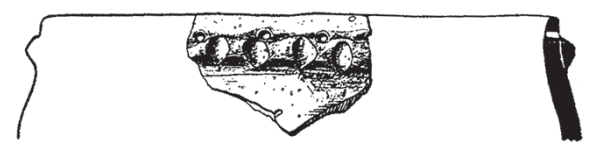

a

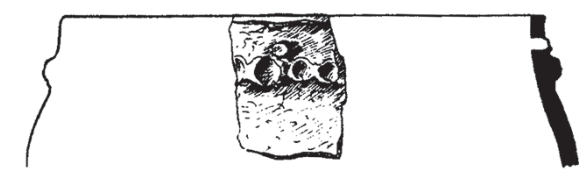

C

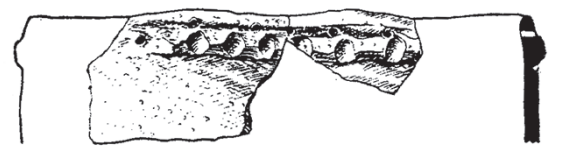

e

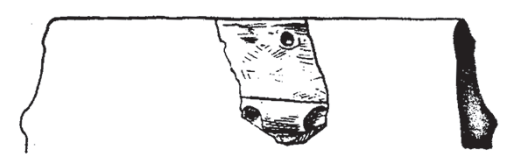

g

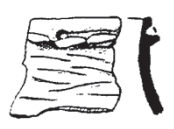

i
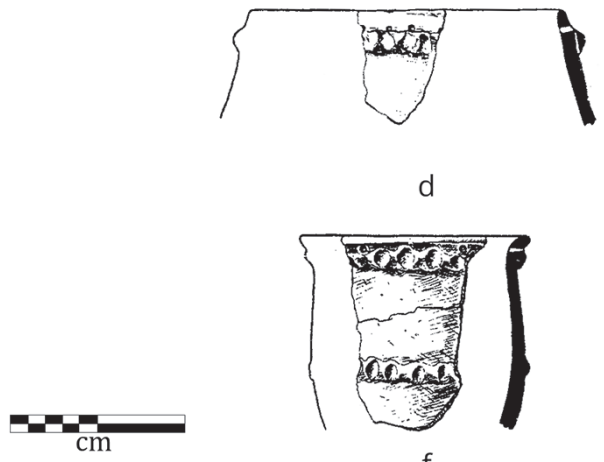

d
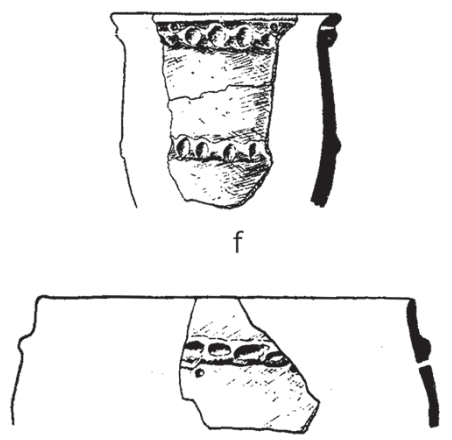

$\mathrm{h}$

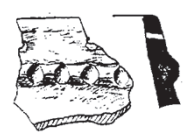

$\mathrm{k}$

Ryc. 6. Ceramika z osady ze stanowiska Czerepin.

Wg Krušel'nic'kiej 1993, ryc. 88:1-3, 6-7, 9, 13, 20-22, 24

Fig. 6. Pottery from the settlement at the Cherepin site.

After Krušel'nic'ka 1993, Fig. 88:1-3, 6-7, 9, 13, 20-22, 24

łohrudowska, sabatinowska, czarnoleska czy biełozierska. W odróżnieniu od nich mniejsze grupy: leżnicka i czerepińsko-łagodowska w swych zwartych zasięgach są podobne do kultur lub grup środkowoeuropejskich.

\section{DYSKUSJA}

W 1993 r. L. Kruszelnyćka sformułowała tezę, że kultura wysocka zanikła w VI w. p.n.e., a zastąpiła ją "kultura rolniczych plemion okresu wczesnoscytyjskiego", bez bliższej identyfikacji, której początki mogły sięgać już VII w. p.n.e. (Krušel'nic'ka 
the Scythian cultural circle (Gejko 2011), especially the pots with holes pierced in their body (not always going right through) and the relief bands placed high on the body (Fig. 6), as well as some types of bowls.

In light of the current body of data, the Lezhnica and Cherepin-Lagodiv group occupy mutually neighboring territories and are the westernmost cultural units of the Early Iron Age recognized in Ukraine. In size, these territories are not unlike those of some Lusatian Cultural Circle units, but they are clearly smaller from that of many eastern European groups occupying large ecumenes already from the Early Bronze Age. Significantly, these large groups show a preference for latitudinal zones, respecting the natural environments of eastern Europe: steppe, forest-steppe, and forest. The cultures in question are the following: Zrubna, Bilokhrudivska, Sabatinovka, Chornoliska and Belozerska. Compared to them, the smaller Lezhnica and Cherepin-Lagodiv groups are similar in their compactness to central European cultures or groups.

\section{DISCUSSION}

In 1993, Krushelnytska went as far as to say that Vysocka culture was replaced in the $6^{\text {th }} \mathrm{c}$. BC by "a culture representing the farming tribes of the early Scythian period", without any closer identification, the origins of which could be traced back even to the $7^{\text {th }}$ C. BC (Krušel'nic'ka 1993, pp. 192-193). She considered it part of a wider process encompassing all of this part of central and eastern Europe. This view now has to be seriously revised, taking into account primarily the synchronous emergence of two of the groups from the Scythian circle described above, namely, the Lezhnica and the Cherepin-Lagodiv groups. Looking at this in the context of the territories of these units (Fig. 1), one notes immediately that the groups occupied part of the earlier ecumene of Vysocka culture. Consequently, the clearly emphasized syncretism of Early Iron Age groups in the region in question should be seen in a different light (Krušel'nic'ka 1976, p. 65). It has its sources both in earlier cultural units (Vysocka culture, but also Lusatian and Gava-Holihrady), as well as in "contemporaries" (Western Podolian group and distant Thracian parallels from Bukowina; Krušel'nic'ka 1976, pp. 65-70, 98-101; eadem 1993, pp. 157-158, 236-238). The undisputed role of Vysocka culture is not in its significant interplay with already established "younger" cultural units (Krušel'nic'ka 1976, pp. 70-71), but in its nature as a substrate for the emerging Lezhnica and Cherepin-Lagodiv groups. There is an obvious mix of different, most frequently neighboring cultural groups, which is especially apparent over large territories of the central and eastern European frontier in the Early Iron Age. This phenomenon is better described by a term borrowed from Elżbieta Kłosińska: "Lusatian-Vysocka zone of cultural intermingling" (Kłosińska 2005, pp. 178-179; eadem 2007, p. 226), rather than by efforts to force the archaeological material into groups and cultures with sharply defined divisions. It is worth noting that Vysocka culture is best known for its burials, whereas settlement finds dominate the record in the case of other cultural units 
1993, s. 192-193). Z dalszych uwag tej autorki wynika, że był to element szerszego procesu, jaki miał miejsce w tej części Europy środkowo-wschodniej. Przyjmując ten pogląd, trzeba jednak dokonać istotnych uzupełnień. Należy zwrócić uwagę przede wszystkim na synchroniczność pojawienia się dwóch scharakteryzowanych wcześniej ugrupowań kręgu scytyjskiego z powstaniem grup leżnickiej i czerepińsko-łagodowskiej. Łącząc ten fakt z zasięgiem tych jednostek wyraźnie widać (ryc. 1), że obejmują one część wcześniejszej ekumeny kultury wysockiej. Inaczej zatem należy spojrzeć na tak bardzo akcentowany synkretyzm ugrupowań z wczesnej epoki żelaza na analizowanym obszarze (Krušel'nic'ka 1976, s. 65). Jego źródeł szuka się zarówno w kulturach wcześniejszych (wysocka, ale też łużycka, Gava-Holihrady), jak i „współczesnych” (grupa zachodniopodolska i odległe, trackie analogie z Bukowiny; Krušel'nic'ka 1976, s. 65-70, 98-101; taż 1993, s. 157-158, 236-238). Rola kultury wysockiej jest bezsporna, ale nie jako zespołu odgrywającego ważną rolę w funkcjonowaniu ukształtowanych już „młodszych” jednostek kulturowych (Krušel'nic'ka 1976, s. 70-71), ale jedynie jako substratu, który dał początek grupie leżnickiej i czerepińsko-łagodowskiej. Mieszanie się cech różnych, najczęściej sąsiadujących ze sobą ugrupowań kulturowych jest oczywiste, a szczególnie widoczne we wczesnej epoce żelaza na dużym obszarze pogranicza Europy środkowej i wschodniej. Lepiej określa to termin zaproponowany przez Elżbietę Kłosińską - „łużycko-wysocka strefa przemieszania kulturowego” (Kłosińska 2005, s. 178-179; taż 2007, s. 226), niż zamykanie materiałów archeologicznych w ostrych granicach grup czy kultur. Warto zwrócić uwagę na fakt, że kultura wysocka jest najlepiej poznana w zakresie źródeł funeralnych, a w innych jednostkach wczesnej epoki żelaza zdecydowanie dominują znaleziska z osad. Podstawą wszelkich porównań i dowodzenia tezy o synkretyzmie grup i kultur jest w tym przypadku ceramika. W literaturze archeologicznej można wskazać prace akcentujące nie tylko formalne rozbieżności naczyń funeralnych i utylitarnych, ale także błędny charakter samego założenia łączącego wytwórczość ceramiczną dwóch sfer - sacrum i profanum, co może nawet odgrywać ważną rolę w datowaniu (Czopek 2014).

Wydaje się, że mamy tu do czynienia z dość istotnymi uproszczeniami. Ich źródłem jest $\mathrm{z}$ jednej strony spłycony czas funkcjonowania grup leżnickiej i czerepińsko-łagodowskiej, a z drugiej - rygorystyczne traktowanie, a nawet trwałość ich ekumen. Skutkiem pierwszej przesłanki jest łączne rozpatrywanie zabytków ruchomych bez względu na ich szczegółową chronologię w obrębie całego okresu ich funkcjonowania oraz bez dokładnej analizy w obrębie stanowisk, które bardzo często bywają przecież wielofazowe. Na podstawie dotychczasowych ustaleń można stwierdzić, że to, co zdecydowało o ich wydzieleniu, a więc „wczesnożelazna” odrębność stylistyczna ceramiki, jest jedynym elementem wspólnym i dobrze je definiującym. Trzeba też zwrócić uwagę, że przywoływane często analogie „łużyckie” (głównie te dotyczące wczesnej epoki żelaza, np. naczynia wazowate $\mathrm{z}$ otworkami pod krawędzią), nie są całkowicie trafne. W polskiej literaturze podkreśla się odwrotny kierunek oddziaływań i analogii. Wynika to $\mathrm{z}$ faktu, że na dużym obszarze Europy środkowo-wschodniej styl ceramiczny co najmniej młodszej części wczesnej epoki żelaza (= HaD), jest bardzo podobny. 
from the Early Iron Age. Pottery is at the base of all comparisons and the reasoning arguing in favor of a syncretism of groups and cultures. The archaeological literature on the subject goes beyond emphasizing the formal differences between funerary and utilitarian vessels and points out the mistaken assumption behind linking pottery production representing two spheres of life, sacrum and profanum; this could even be of importance for dating (Czopek 2014).

Rather significant simplifications seem to be involved here. One source of this is the narrowed timeframe for the functioning of the Lezhnica and Cherepin-Lagodiv groups, another a rigorous approach to the territorial extent (and even permanence) of their ecumenes. The first of these premises results in considering all the mobile artifacts in one bag, so to speak, without paying attention to their detailed chronologies within the groups' established period of functioning and without an in-depth analysis of their place within the frequently multi-phase stratigraphy of given sites. The conclusion to be drawn from the current examination of the material is that the "Early Iron Age" stylistic distinctness of the pottery that was at the root of the identification as a separate unit was the sole connecting and well-defining feature between them. Frequently cited Lusatian parallels (mainly from the Early Iron Age, such as vases with pierced holes under the rim) are not quite correct. An opposite vector of the impact and parallels is emphasized in the Polish literature on the subject, deriving from the strong similarities of the pottery style in a large part of central and eastern Europe during at least the younger phases of the Early Iron Age $(=\mathrm{HaD})$.

One should point out the potential territorial relations, which in any case are not clearly defined, between the Lezhnica and Cherepin-Lagodiv groups. It is suggested by the similarities observed in the pottery, which is the most commonly encountered archaeological material. Both groups have produced vessels of the same or very similar type: pots with coarse surfaces, disk-plates, bowls with incurved rim, vases of the "Lusatian type". The similarity is evident primarily for materials of eastern provenience from the Early Iron Age. Other elements, mainly of older date, e.g., cultural relations, which have been emphasized in the literature, may contribute to a characteristic of the culture, but do not define it, especially with regard to the Early Iron Age. Of key importance for the present discussion is the period when similar pottery characteristics, manifested in the style (pots with holes under the edge and relief decoration, bowls with incurved rims, disk-plates) and technology (grog as temper), become common over a broader region of central and eastern Europe. Next to the ceramics are the metal and bone artifacts, which are indisputably linked to the Scythian world (e.g. Bukowski 1977; Kłosińska 2013). It concerns the two groups under discussion as well as others in neighboring territories (Kłosińska 2007, pp. 235-237; Trybała-Zawiślak 2019, pp. 96-182). The Gonczarówka site in Zlochiv district is an excellent case in point with pottery of the "Eastern type" (pots with high plastic bands and pierced holes, bowls with incurved rims) found together with remains of a metal-casting workshop producing "Scythian" arrowheads (Il'čišin, Grečko 2018). The discovery matches in significance the metal workshop for producing nail-headed earrings that was uncovered several dozen years ago at Połaniec 
Należy też zwrócić uwagę na ewentualne relacje terytorialne między grupą leżnicką i czerepińsko-łagodowską, które nie są jednoznacznie określone. Wynika to ze zbieżności cech najliczniej występującego materiału zabytkowego, tj. ceramiki. W obydwu grupach znajdziemy te same lub bardzo podobne typy: garnki o chropowatej i szorstkiej powierzchni, talerze-placki, misy z brzegiem zagiętym do środka, naczynia wazowate „typu łużyckiego”. Ta zbieżność czytelna jest wyraźnie przede wszystkim wśród materiałów o tzw. wschodniej proweniencji z wczesnej epoki żelaza. Akcentowane w literaturze inne elementy (np. związki kulturowe), głównie o starszej chronologii, mogą w jakimś zakresie charakteryzować te jednostki, ale raczej ich nie definiują, zwłaszcza w odniesieniu do wczesnej epoki żelaza. Za kluczowy dla naszych rozważań należy uznać moment, w którym na szerszym obszarze Europy środkowo-wschodniej upowszechniają się podobne cechy ceramiki, manifestujące się w stylistyce (garnki z otworkami pod krawędzią i zdobnictwem plastycznym, misy z brzegiem zagiętym do środka, talerze-placki) i technologii (tłuczeń ceramiczny w domieszce). Obok nich pojawiają się też przedmioty metalowe i kościane, które jednoznacznie są wiązane ze światem scytyjskim (np. Bukowski 1977; Kłosińska 2013). Dotyczy to także omawianych dwóch grup i obszarów sąsiednich (Kłosińska 2007, s. 235-237; Trybała-Zawiślak 2019, s. 96-182). Bardzo znamienny jest przykład osady w Gonczarówce, raj. Złoczów, gdzie obok ceramiki w typie „wschodnim” (garnki z wysokimi listwami i otworkami, misy z brzegiem zagiętym do środka naczynia) odkryto ślady pracowni odlewniczej, w której produkowano „scytyjskie” grociki do strzał (Il’čišin, Grečko 2018). Odkrycie to ma duże znaczenie, podobne do pochodzącego sprzed kilkudziesięciu lat zidentyfikowania pracowni odlewniczej zausznic gwoździowatych w Połańcu, w pow. staszowskim (Michalski 1982). W obydwu przypadkach, daleko poza znaną ekumeną plemion o scytyjskim modelu kultury materialnej, zostały zarejestrowane miejsca wytwarzania przedmiotów uważanych za jej wyznacznik.

Odkrycie w Chotyńcu i jego okolicach scharakteryzowanego wyżej skupiska osadniczego zmusza do kolejnych reinterpretacji dotychczasowych ustaleń. Trudno jeszcze precyzyjnie określić źródło pochodzenia wschodniej grupy osadników, ale ich związki z leśnostepową kulturą scytyjską nie budzą wątpliwości. Mamy bowiem potwierdzoną nie tylko kulturę materialną, która w znacznie mniejszym zakresie jest znana także z innych obszarów, ale nową obrzędowość (zolnik, import greckiego wina) i nieznany tu wcześniej system osadniczy. Samo ponad trzydziestohektarowe grodzisko świadczy też o dobrze zorganizowanej (zarządzanej?) wspólnocie. Zarówno z kultury wysockiej, jak i grup czerepińsko-łagodowskiej oraz leżnickiej nie są znane grodziska i większość cech kultury materialnej pochodzącej z chotynieckiego zolnika. Ważnym pytaniem jest: czy, a jeżeli tak, to w jakim zakresie aglomeracja chotyniecka łączy się z osadnictwem grupy zachodniopodolskiej? Uzasadnione wątpliwości może budzić zbyt duża odległość dzieląca te dwa ugrupowania. Proste zmierzenie na mapie dzielącego je dystansu daje $200-400 \mathrm{~km}$. Nie budzące wątpliwości źródła i ich interpretacja wskazują w zasadzie na dwie możliwości wyjaśnienia tego faktu. Pierwsza, to uznanie samodzielności skupiska chotynieckiego, niezależnego od grupy zachodniopodolskiej. Za taką interpretacją przema- 
in the Staszów district (Michalski 1982). In both instances, artifacts considered as a cultural marker of tribes displaying a Scythian model of the material culture were being made in places far beyond the known ecumene of this cultural circle.

The findings to date are in need of reinterpretation following the discoveries made at Chotyniec and in the complex in its neighborhood. The source of origin of the eastern group of settlers is still difficult to pin down precisely. However, the group's ties with the forest-steppe Scythian culture are undisputed, both in terms of the material culture, which is present in other territories to a much lesser extent, and in terms of a new rituality (zolnik, imports of Greek wine) and a previously unknown kind of settlement network. The 30 ha of the hillfort testify to a well organized (well managed?) community. Hillforts and most of the material culture characteristics observed on the Chotyniec zolnik are unknown to Vysocka culture and the Cherepin-Lagodiv and Lezhnica groups. An important issue to consider is whether, and if so, then to what extent, the Chotyniec complex was connected with Western Podolian settlement. The distance between the two groups - 200 to $400 \mathrm{~km}$ measured with a ruler on the map - raises justified doubts. Sources that are undisputed, and their interpretation, indicate two possible explanations. First, that the Chotyniec complex was independent of the Western Podolian group. Arguing in favor of this idea are the chronological differences discussed above, concerning the phasing out of both units. However, they share both origin and chronology of appearance. The other approach is to assume that territorial discontinuity is a reflection of the state of research. Fieldwork in the Wisznia basin (Czopek et al. 2018) has confirmed even highly intensive settlement in the Early Iron Age, but attribution to a specific cultural group is difficult based on a random study of surface finds of undoubted chronology. One should note the barrow from Byków near Drohobych, clearly related to the Western Podolian group as attested by the inventory of finds and sepulchral ritual characteristics (Czopek et al. 2016). It is the northwestern-most site of this unit, definitely closer to the Chotyniec complex than to the main interior of this group (Fig. 2). The research potential of the region east of Chotyniec is substantial, lying as it does on the main route between the eastern and western territories, but more extensive fieldwork is in order. One should mention here the numerous barrows found there, including very large ones (diameters of 30-40 m and more, see Czopek, Wojceszczuk 2018), of unclear chronology and cultural attribution.

The Mogiliany group, which has not been discussed here so far (Dąbrowski 1972, p. 170; Krušel'nic'ka 1976, pp. 72-82; eadem 1990, pp. 146-148), also contributes important data. The independence of this group has been emphasized for a long time, as demonstrated by its classification as a slightly earlier group than the Lezhnica and Cherepin-Lagodiv groups (end of the Bronze Age), at least according to the state of research at the time. Current knowledge on the subject accepts this view with significant additions concerning the youngest phase. The Mogiliany material culture includes artifacts (Fig. 7) evidently from the Scythian forest-steppe zone (Węgrzynowicz 2001, pp. 78-79). The situation is analogous to that of the earlier discussed groups. A distinct element is superimposed on the older phase of the 
wiają wskazane już różnice chronologiczne dotyczące schyłku obydwu podmiotów. Ich początek jest jednak analogiczny, zarówno co do czasu powstania, jak i samej genezy. Druga, to założenie, że brak ciągłości terytorialnej wynika ze stanu badań. Prace prowadzone w dorzeczu Wiszni (Czopek i in. 2018) potwierdziły obecność osadnictwa (nawet bardzo intensywnego) we wczesnej epoce żelaza. Trudno jednak na podstawie wyrywkowej znajomości materiału powierzchniowego, o niebudzącej wątpliwości chronologii, przypisać je do określonej grupy kulturowej. Należy w tym miejscu odnotować kurhan z Bykowa koło Drohobycza, jednoznacznie związany z grupą zachodniopodolską ze względu na inwentarz i cechy obrzędowości funeralnej (Czopek i in. 2016). Stanowisko to jest najdalej na północny zachód wysuniętym punktem tej jednostki. Leży ono zdecydowanie bliżej aglomeracji chotynieckiej niż głównego interioru tej grupy (ryc. 2). Potencjał badawczy regionu na wschód od Chotyńca, leżącego na szlaku między wschodem a zachodem, jest bardzo duży, ale wymaga dalszych, szerzej zakrojonych badań terenowych. Należy w tym miejscu wspomnieć o dość licznie występujących tam kurhanach, w tym bardzo dużych (o średnicach 30-40 i więcej metrów - por. Czopek, Wojceszczuk 2018), o niejasnej chronologii i przynależności kulturowej.

Pomijana do tej pory w naszych rozważaniach grupa mogilańska (Dąbrowski 1972, s. 170; Krušel'nic'ka 1976, s. 72-82; taż 1990, s. 146-148) również dostarcza ważnych informacji. Odrębność tej jednostki była akcentowana od dawna, co przejawiało się w uznaniu jej za nieco wcześniejszą (koniec epoki brązu) niż grupy leżnicka i czerepińsko-łagodowska, oczywiście według ówczesnego stanu badań. $\mathrm{Z}$ dzisiejszej perspektywy można to zaakceptować, ale konieczne jest istotne uzupełnienie odnośnie do jej najmłodszej fazy. Otóż, do materiałów grupy mogilańskiej zaliczane są przedmioty (ryc. 7) ewidentnie pochodzące ze strefy scytyjskiego lasostepu (Węgrzynowicz 2001, s. 78-79). Mamy zatem analogiczną sytuację jak w poprzednich grupach. Na etap starszy nakłada się wyraźny element, który można uznać za proces „scytyzacji” kultury materialnej. Jego źródeł w tym przypadku nie należy szukać nad Dniestrem, ale raczej nad górnym Bohem lub nawet bezpośrednio nad Dnieprem. Grupa mogilańska jest bowiem wyróżniana na obszarze na wschód od grupy leżnickiej, w górnych dorzeczach prawobrzeżnego Styru, Horynia i Słuczy, a więc na stosunkowo dużym obszarze, znacznie oddalonym od naddniestrzańskiej prowincji kręgu scytyjskiego.

Rozpatrując dokładną chronologię zmian osadniczych i kulturowych na zachodnim Wołyniu i Podolu, a także nawiązując do wielokrotnie akcentowanego

Ryc. 7. Zabytki ze stanowisk Cyceniówka (a-b), Ihłowica Mała I (c, h) i III (d-g) przypisywanych grupie mogilańskiej oraz przedmioty ze stanowisk grupy zachodniopodolskiej w Iwahnowcach I (i-m, o-t) i II (n).

Wg Węgrzynowicz 2001, ryc. 5; 10b-s

Fig. 7. Artifacts from the Cyceniówka site (a-b), Ihłowica Mała I (c, h) and III (d-g) attributed to the Mogiliany group and from sites of the Western Podolian group in Iwahnowce I ( $\mathrm{i}-\mathrm{m}, \mathrm{o}-\mathrm{t})$ and II (n).

After Węgrzynowicz 2001, Fig. 5; 10b-s 


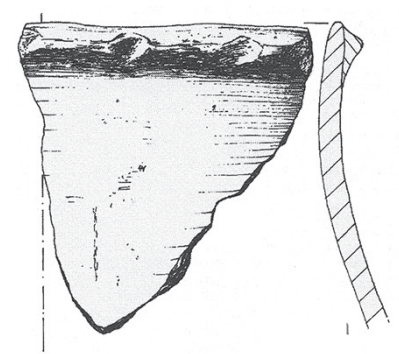

a
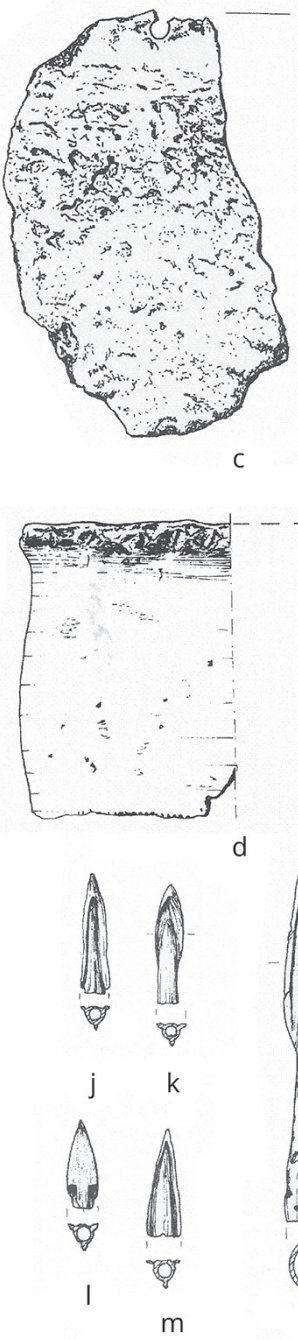

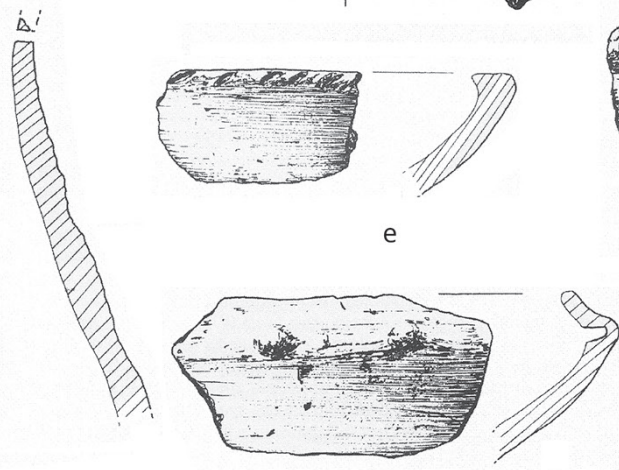

g
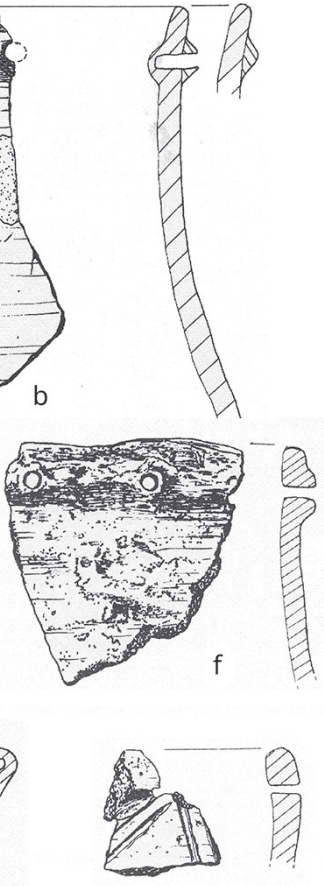

h
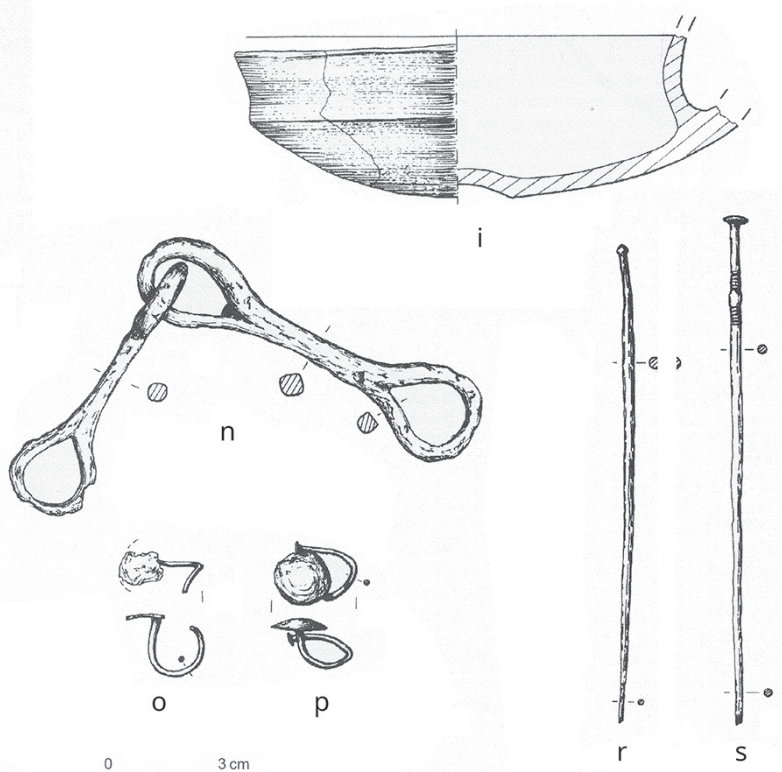
synkretyzmu, należy jeszcze zwrócić uwagę na sam schyłek epoki brązu i sam początek wczesnej epoki żelaza $(=\mathrm{HaC})$. Główną rolę przypisuje się wówczas młodszej fazie ugrupowania Gava-Holihrady. Problem ten od dawna był sygnalizowany w literaturze (Krušelnicka 1979) i jest ciągle obecny (Gawlik, Przybyła 2005, s. 339; Kłosińska 2007, s. 232; Bandrivs'kij 2014, s. 25-185), ale wymaga dokładniejszych badań interregionalnych (Trybała-Zawiślak 2019, s. 56-70). Niejasny jest też ewentualny, zapewne nieco późniejszy, komponent czarnoleski, łącznie z typem żabotińskim (Trybała-Zawiślak 2019, s. 183-213). Szczególnie ważny z punktu widzenia niniejszych rozważań jest ten ostatni. Charakteryzująca go ceramika zawiera bowiem także cechy, które są powtarzalne $\mathrm{w}$ zestawie form przewodnich okresu scytyjskiego w strefie lasostepu. Mowa o garnkach $\mathrm{z}$ listwami i otworkami pod krawędzią oraz misach z brzegiem zagiętym do środka naczynia i quasi otworkami. Charakteryzują one fazę Żabotin III, która jest datowana od końca VIII do 2 poł. VII w. p.n.e. (Daragan 2004, s. 132-133). Ważne jest przy tym, że na Podnieprzu jest ona współczesna najstarszym materiałom scytyjskim. W przypadku materiałów z obszaru zachodniej Ukrainy i południowo-wschodniej Polski trudno obecnie definitywnie stwierdzić, czy są one efektem infiltracji „przedscytyjskiej”, czy też stanowią pewien (archaiczny?) komponent, np. wśród ludności aglomeracji chotynieckiej, którą identyfikujemy z kręgiem scytyjskim. Mogą to potwierdzać najstarsze daty radiowęglowe, sięgające nawet IX w. p.n.e. (Trybała-Zawiślak 2019, s. 286-290). Z ostatecznymi wnioskami trzeba jednak poczekać do zakończenia badań.

Na koniec należy powrócić do sygnalizowanej już, choć nie nowej (por. Czopek 2007) tezy o obecności na interesującym nas terenie Neurów (Kozak 2012, s. 35). Stanowi ona problem trudny do rozwiązania, przede wszystkim ze względu na niejednoznaczną wymowę źródeł. Dotyczy to w równym stopniu archeologii, jak i skąpych danych historycznych, obecnych w zasadzie tylko w Dziejach Herodota. Nie powtarzając obecnych od wielu lat w literaturze poglądów, przypomnijmy jedynie tezę Kazimierza Moszyńskiego z lat pięćdziesiątych XX w., w której jednoznacznie (w przeciwieństwie do innych badaczy) opowiedział się za uznaniem wędrówki Neurów ze wschodu na zachód, co miało mieć miejsce jeszcze przed wyprawą Persów na Scytię (tj. w końcu VI w. p.n.e.). W wieku V, tj. w czasach, w których powstało dzieło herodotowe, Neurowie są już sąsiadami Agatyrsów i Androfagów, zamieszkując tereny poza źródłami Tyrasu/Dniestru (Moszyński 1954). W tym kontekście po raz kolejny należy przywołać Chotyniec, dokładnie odpowiadający takiej lokalizacji. Inni badacze (np. Mozolewskij 2013, ryc. 7) umieszczają Neurów bezpośrednio za granicą zachodniej części leśnostepowej Scytii, na północ od Scytów-Oraczy. Strefa zajęta przez tych ostatnich jest bardzo różnie rozumiana, w wąskim lub bardzo szerokim zakresie terytorialnym, stąd także alternatywne lokalizacje Neurów, np. w dorzeczu Prypeci (Rybakov 1979, s. 97, 145-148). M. Bandriwśkyj widzi wielką Neurydę (nie tylko w czasach wczesnej epoki żelaza, ale także wcześniejszych), obejmującą przede wszystkim grupy prawobrzeżnego lasostepu, uważane z zasady za scytyjskie. Uznaje ją za „wyjątkowe historyczno-geograficzne zjawisko" (Bandrivs'kij 2014, s. 401-403). 
unit, constituting evidence of a process of "Scythization" of the material culture. The source in this case would not be the Dniester area, but the region on the upper Boh or even directly on the Dnieper. This is because the Mogiliany group has been distinguished east of the Lezhnica group, in the basins of the upper runs of the rightbank Styr, Horyn and Sluch, which is a relatively large territory at a considerable distance from the Dniester province of the Scythian circle.

Looking at the precise chronology of settlement and cultural change in Western Volhynia and Podolia, and referring to the frequently emphasized syncretism that can be observed, one still needs to consider the close of the Bronze Age and the very beginning of the Early Iron Age $(=\mathrm{HaC})$. The younger phase of the Gava-Holihrady group is assigned the role of chief player in this period. The issue was signaled in the literature a long time ago (Krušelnicka 1979) and is still present (Gawlik, Przybyła 2005, p. 339; Kłosińska 2007, p. 232; Bandrivs'kij 2014, pp. 25-185), requiring more detailed inter-regional research (Trybała-Zawiślak 2019, pp. 56-70). The potential, presumably slightly later, Chornoliska component, together with the Zhabotin type, is also unclear (Trybała-Zawiślak 2019, pp. 183-213). The last mentioned is particularly important for the present discussion. The pottery that characterizes this unit contains features that are repeated in the set of key forms for the Scythian period in the forest-steppe zone, namely, the pots with bands and holes pierced under the rim and the bowls with incurved rims and pseudo-holes. These are found in the Zhabotin III phase, which is dated from the end of the $8^{\text {th }}$ to $2^{\text {nd }}$ half of the $7^{\text {th }}$ centuries BC (Daragan 2004, pp. 132-133). It is also significant that this phase is contemporary with the oldest Scythian material in the Dnieper region. In the case of material from western Ukraine and southeastern Poland, it is currently impossible to be definite about whether we are dealing with the effects of a "pre-Scythian" infiltration or a certain (archaic?) component, for instance, among the people making up the Chotyniec complex, who are identified with the Scythian circle. The oldest radiocarbon dates, reaching into the $9^{\text {th }} \mathrm{c}$. BC, appear to confirm this view (Trybała-Zawiślak 2019, pp. 286-290). Research will have to be completed before final conclusions can be drawn.

Last but not least, one should reconsider the theory signaled above, which however is not new (see Czopek 2007), about the presence of the Neuri in the territories under discussion (Kozak 2012, p. 35). The issue is difficult to resolve, mainly because of the ambiguity of the sources, the archaeological ones equally so as the modest historical ones, the latter actually limited only to the History of Herodotus. Without reviewing all the opinions voiced over the years, let us recall the one of Kazimierz Moszyński from the 1950s, arguing (contrary to other researchers) in favor of a migration of the Neuri from east to west at a time preceding the Persian expedition against the Scythians (that is, in the end of the $6^{\text {th }} \mathrm{c}$. BC). In the $5^{\text {th }} \mathrm{c}$. $\mathrm{BC}$, at a time when Herodotus was writing, the Neuri were already neighbors with the Agathyrsii and Androphagi who inhabited the territories beyond the sources of the Tyras/Dniester (Moszyński 1954). In this context, let us recall Chotyniec once again, which is located exactly in this region. Other researchers (e.g. Mozolewskij 2013, Fig. 7) see the Neuri directly beyond the western border of the forest-steppe 
To, co wiemy o kulturze Neurów nie wykracza poza bardzo ogólne sformułowanie o ich „scytyjskich obyczajach” i od wielu lat wzbudza dyskusje (Rybakov 1979, s. 145; Czopek 2007, s. 416-417). W tej chwili trudno o lepszy przykład niż chotyniecki zolnik ze śladami cyklicznych obrzędów libacyjnych z greckim winem, importowanym w glinianych amforach, dość licznie obecnych w warstwach zolnikowych (Trybała-Zawiślak 2019, s. 268-273; Czopek 2019, s. 126-129). Drugą bardzo ważną wzmianką jest ta, w której mowa o „królestwie Neurów” (ich król miał brać udział w naradzie Scytów, zwołanej w obliczu zbliżającej się armii perskiej), a więc o relatywnie dużym obszarze (stąd Neuryda). Uwagi te nie przesądzają o rozstrzygnięciu problemu obecności tego ludu na Wołyniu i zachodnim Podolu, a nawet szerzej - na terenie co najmniej wschodniej Polski (Kłosińska 2007, s. 240; Ignaczak 2016, s. 179-180). Poszerzają jednak granice interpretacji rejestrowanych obecnie faktów archeologicznych, które wykraczają poza tradycyjnie rozumiane jednostki kulturowe.

\section{WNIOSKI}

W świetle dotychczasowych uwag można sformułować następujące wnioski:

1. Odkrycia w Chotyńcu w sposób bardzo znaczący wymuszają refleksję czy nawet zmianę dotychczasowych poglądów na sytuację kulturowo-chronologiczną we wczesnej epoce żelaza na południowo-zachodnim Wołyniu, zachodnim Podolu i na obszarze południowo-wschodniej Polski, a więc na granicy Europy środkowej i wschodniej. Pojawia się bowiem ważne skupisko osadnicze, trwające nawet kilka stuleci, które może być traktowane jako obszar wyjściowy wielu impulsów i konkretnych importów materialnych do stref leżących na zachód i północ od niego. Coraz większa liczba materiałów, w tym także ceramiki, które nie zawsze można interpretować jako importy, świadczy o silniejszych niż do tej pory przyjmowano kontaktach z szeroko pojmowanym światem scytyjskim dużej strefy - od wschodniej Polski po Wołyń.

2. Na początek wczesnej epoki żelaza (= HaC1, tj. IX/VIII-VIII w. p.n.e.; Trachsel 2004) przypada czas bardzo ważnych zmian kulturowych na całym pograniczu środkowo- i wschodnioeuropejskiej prowincji kulturowej. W źródłach archeologicznych jest on obserwowany jako schyłek kultur wywodzących się z epoki brązu, które także wykazują pewną aktywność osadniczą w nowych regionach. Pojawiają się też ślady obecności wschodnioeuropejskich koczowników (Kimmerów).

3. Co najmniej od połowy VII w. $(=\mathrm{HaD})$, a według niektórych autorów nawet od końca VIII w. p.n.e. (= HaC2), notujemy obecność materiałów, które jednoznacznie wskazują na związki z wschodnioeuropejską prowincją leśnostepowego kręgu scytyjskiego. Dotyczy to z całą pewnością grup: zachodniopodolskiej, czerepińsko-łagodowskiej, leżnickiej i aglomeracji chotynieckiej, a na obszarach położonych dalej na zachód - tarnobrzeskiej kultury łużyckiej. Bez wątpienia doszło wówczas do istotnych przemieszczeń ludnościowych, bowiem masowo pojawia się ceramika, dla której zarówno ze względu na technologię, jak i stylistykę próżno szukać 
part of Scythia, north of the territories inhabited by the Scythian Plowers. The zone that the latter occupied is understood very differently in territorial terms, either narrowly or very broadly, hence the alternative localizations of the Neuri, for example, in the basin of the Prypiat (Rybakov 1979, pp. 97, 145-148). Bandrivskyi sees the Great Neurs (in the Early Iron Age, but earlier as well), encompassing primarily the right-bank forest-steppe groups considered as Scythian, and refers to it as an "exceptional historical and geographical phenomenon" (Bandrivs'kij 2014, pp. 401-403).

We know little about the Neuri beyond some generalities concerning their "Scythian customs" and the debate is ongoing (Rybakov 1979, p. 145; Czopek 2007, pp. 416-417). The Chotyniec zolnik with evidence of cyclical libation rites using Greek wine imported in clay amphorae, which are relatively well represented in the material from the ritual cult place, is the best example today (Trybała-Zawiślak 2019, pp. 268-273; Czopek 2019, pp. 126-129). A second important mention is that of the "kingdom of the Neuri" (their king was supposed to have participated in a war council of the Scythians called in the face of the approaching Persian army), which is indicative of a relatively large territory (hence Great Neurs). These remarks do not forejudge on the presence of these people in Volhynia and western Podolia, and even perhaps more broadly, in the territory of at least eastern Poland (Kłosińska 2007, p. 240; Ignaczak 2016, pp. 179-180). However, they broaden the boundaries of interpretation of archaeological facts on record today, which go beyond traditionally understood cultural units.

\section{CONCLUSIONS}

The following conclusions can be made in the light of the above:

1. The Chotyniec discoveries force reflection and even change of previous views on the cultural and chronological situation in the Early Iron Age in southwestern Volhynia, western Podolia and southeastern Poland, that is, the border between central and eastern Europe. Chotyniec represents an important settlement complex which lasted several centuries and which can be considered as a source of cultural influence and specific material imports for the regions north and west of it. A growing assemblage of finds, including pottery which cannot always be considered as an import, testify to stronger than hitherto assumed contacts of the large territories of eastern Poland, all the way to Volhynia, with a broadly understood Scythian world.

2. Important cultural change was in progress along the entire border of the central and eastern European province at the onset of the Early Iron Age $(=\mathrm{HaCl}$, that is, $9^{\text {th }} / 8^{\text {th }}-8^{\text {th }}$ centuries BC; Trachsel 2004). In the archaeological record, it is observed as the fading of Bronze Age cultures, which also demonstrated some settlement activity in new regions. Traces of the Kimmerians, the eastern European nomads, are also present in the record.

3. From the mid $7^{\text {th }} \mathrm{c}$. BC at least $(=\mathrm{HaD})$, perhaps even the end of the $8^{\text {th }} \mathrm{c}$. $\mathrm{BC}(=\mathrm{HaC} 2)$ according to some researchers, there is undisputed evidence in the archaeological record of ties with the eastern European province of the forest-steppe 
miejscowych korzeni. Wymowa źródeł ceramicznych jest tu godna podkreślenia. Dotychczas zwracano bowiem uwagę przede wszystkim na znaleziska zabytków metalowych, których jednoznacznie „scytyjska - leśnostepowa” proweniencja nie budziła wątpliwości, ale traktowano je jako importy, czasami bardzo odległe. Należy zatem przyjąć, że w całej omawianej strefie - od Chotyńca po południowy Wołyń i górne dorzecze Dniestru (zachodnie Podole) dochodzi wówczas do istotnej zmiany kulturowej, inspirowanej przybyciem nowej grupy ludności leśnostepowej. Uruchomione zostają szybkie procesy akulturacyjne. Ich katalizatorem była polityczna i militarna obecność grup o „scytyjskiej” kulturze materialnej. Proces ten można nazwać „scytyzacją”. W starszej literaturze był on dostrzegalny jedynie szczątkowo na podstawie rozprzestrzenienia się zabytków brązowych, głównie grocików do strzał. Teraz należy brać pod uwagę i inne elementy kultury materialnej, a przede wszystkim ceramikę. W jej rozpowszechnieniu można wykazać dwutorowość. Szlak (strefę) wschodni, znad Bohu w kierunku Prypeci i zachodni, znad Dniestru, w tym Chotyńca, w kierunku Bugu i Wisły.

4. Bardzo ważny dowód znajdujemy w aglomeracji chotynieckiej, gdzie oprócz przedmiotów rejestrujemy także zmianę systemu osadniczego z centralnym grodziskiem i osadami otwartymi, których wewnętrzna organizacja jest wyraźnie odmienna od dotychczasowych, miejscowych wzorców. Chodzi o „wyspowe” zgrupowania (skupiska) obiektów w ramach jednej przestrzeni osadniczej. Obecność zolnika na chotynieckim grodzisku wskazuje też na przejęcie „wschodniej” obyczajowości lub wierzeń. Natomiast greckie amfory na wino potwierdzają istnienie zróżnicowania społecznego, bowiem ten importowany trunek był związany raczej z wyższymi warstwami, np. arystokracją. W sposób wyraźny potwierdza to relacja Herodota, w której jest mowa o obrzędach organizowanych przez zwierzchnika pewnego obszaru (w tłumaczeniu występuje jako „naczelnik powiatu”), zapewne arystokraty. Sama interpretacja skupiska osadniczego w Chotyńcu nie jest jeszcze jednoznaczna. To niewątpliwie wyjątkowe miejsce sugeruje istnienie albo centralnego, dla szerszej prowincji, ośrodka administracyjnego, albo jedynie graniczną strażnicę - bramę wielkiej Scytii. Możliwe jest oczywiście połączenie tych funkcji. Ewentualne granice tak rozumianej prowincji są trudne do ustalenia. Na zachód od Chotyńca spotykamy wprawdzie podobne artefakty, ale mają one kontekst miejscowej, tarnobrzeskiej kultury. Ewentualnych obszarów związanych z aglomeracją należy szukać raczej na wschodzie. Ostatnie badania prowadzone w dolinie Wiszni (Czopek i in. 2018) wskazały dość liczne stanowiska datowane na wczesną epokę żelaza, ale o niejednoznacznym obliczu kulturowym. Jest wielce prawdopodobne, że to właśnie tam należy szukać podobnych materiałów. Wskazuje na to liczna obecność militariów scytyjskich o szerokim datowaniu, także młodszych niż VI w. p.n.e.

5. W przypadku epoki żelaza w omawianej części Europy trudno jest mówić o wyodrębniających się kulturach i grupach, bowiem obserwujemy bardzo wyraźną unifikację cech kultury materialnej, dobrze ilustrowaną przez stylistykę ceramiki. Ten bardzo ważny fakt ma znaczenie nie tylko źródłoznawcze, ale także bardziej ogólne. Wydaje się, że uporządkowany świat grup i kultur epoki brązu, z przypi- 
part of the Scythian circle. This concerns with all certainty the Western Podolian, Cherepin-Lagodiv, and Lezhnica groups and the Chotyniec agglomeration, as well as the Tarnobrzeg Lusatian culture located further west. Significant population dislocation is attested by a mass appearance throughout the region of a pottery that is not rooted in local tradition either in artistic style or technological execution. The data provided by the ceramic material is worth emphasizing, considering that before this only metal artifacts had attracted attention. Their "forest-steppe-Scythian" provenance raised no doubts, but they were treated as imports, sometimes even very distant ones. Therefore, one should assume a significant cultural change, inspired by the arrival of a new population represented by the forest-steppe tribes, occurring in the entire zone, from Chotyniec to southern Volhynia and the upper Dniester (western Podolia). Rapid acculturation took place - one could call it "Scythization" - triggered by the political and military presence of a group characterized by a "Scythian" material culture. The process had been noted in earlier literature on the subject solely as a distribution of specific bronze artifacts, notably arrowheads. Now other components of the material culture, pottery in particular, need to be taken into account. It is already possible to trace two directions of distribution: the eastern route (zone), from the Boh to the Prypiat, and the western one, from the banks of the Dniester, including Chotyniec, toward the Bug and the Vistula rivers.

4. Chotyniec has contributed important evidence also with regard to the settlement system, the hillfort and the agglomeration of open sites around it, highlighting an internal organization that is clearly distinct from previous local models. It consists of "island" groupings (clusters) of features within one settlement space. The zolnik in the Chotyniec hillfort also signifies assimilation of "eastern" rites and beliefs. The presence of Greek wine amphorae confirms social differentiation because wine is a beverage associated rather with the higher echelons of society, e.g. the aristocracy. Herodotus's report illustrates this quite clearly, mentioning rites organized by the superior of a certain area ("district head, governor of a province" in translation), an aristocrat in all likelihood. The interpretation of the Chotyniec network of settlements is in itself not clear. This exceptional site suggests either a central administrative center for a larger province or merely a border post, the gate to Great Scythia. Indeed, the two functions could have been combined. The borders of the tentative province, as suggested here, cannot be easily established. Similar artifacts are encountered west of Chotyniec, but there they are in the context of the local Tarnobrzeg Lusatian culture. For territories connected with this agglomeration one should rather look east. Recent fieldwork in the Wisznia basin (Czopek et al. 2018) indicated fairly numerous Early Iron Age sites of unclear cultural attribution. It is highly likely that similar archaeological material will be found there. Suffice it to mention the extensive evidence of broadly dated Scythian militaria, including artifacts younger than the $6^{\text {th }} \mathrm{c}$. BC.

5. It is difficult to speak of the Iron Age in this part of Europe in terms of distinctive cultures and groups, because what can be observed is a clear unification of the material culture, well illustrated by pottery styles. This observation has more general implications than just its importance for the study of sources. It would appear that 
sanymi im cechami oraz, co najważniejsze, precyzyjnie określanymi granicami we wczesnej epoce żelaza, już nie istnieje. Tradycyjne narzędzie porządkujące źródła (kultura, grupa kulturowa) nie pozwala teraz na wyjaśnienie zachodzących przemian osadniczych, ludnościowych, a zapewne także etnicznych. Podkreśla to także M. Bandriwśkyj, pisząc o niemożliwości wydzielania grup w „strefie neuryjskiej” (Bandrivs'kij 2014, s. 402). W przeciwieństwie jednak do niego obszar ten może należy widzieć na północ od właściwej Scytii leśnostepowej, a więc także na obszarze Wołynia i jeszcze dalej położonych terenach. Można chyba do wyjaśnienia sytuacji kulturowej w Europie wschodniej wykorzystać model centrum - peryferie. Centrum to oczywiście Scytia stepowa wraz z greckimi koloniami nadczarnomorskimi. Otaczający ją pas lasostepu z grupami rolniczymi to obszar przejściowy o silnej obecności cech materialnej i symbolicznej kultury scytyjskiej. Wreszcie na północ od niego należałoby lokalizować peryferyjne ugrupowania lokalne Neurydy, będące pod wyraźnym wpływem (możliwe, że nawet polityczno-militarnym) scytyjskiego centrum. Z tych właśnie względów wypada zanegować zasadność wydzielania (dla wczesnej epoki żelaza) grup leżnickiej oraz czerepińsko-łagodowskiej i ich dotychczasowej interpretacji. Tak silnie akcentowany ich synkretyczny charakter nie w pełni tłumaczy stan faktyczny, będąc raczej nieporadnym wytrychem niż kluczem do otwarcia drzwi, za którymi możemy obserwować rzeczywistość wczesnej epoki żelaza na Wołyniu i zachodnim Podolu. 
the well ordered world of Bronze Age cultures and groups with their distinctive traits and more importantly, stiffly determined borders ceased to exist in the Early Iron Age. Traditional tools for classifying sources (culture, cultural group) fail to be effective in the face of the population and settlement, and presumably also ethnic changes characterizing this period. Bandrivskij emphasized this as well when admitting the impossibility of distinguishing groups in the "Neurs' zone" (Bandrivs'kij 2014, p. 402). Unlike this researcher, however, one should perhaps look for this territory north of the forest-steppe Scythia proper, consequently also in the region of Volhynia and beyond. The "center-periphery" model is applicable in this case to explain the cultural situation in eastern Europe, the center being naturally the steppe zone of Scythia with the Greek colonies in the Black Sea littoral. The forest-steppe zone around it, inhabited by the agricultural groups, would constitute a transitional zone with a strong presence of Scythian material and symbolic culture. And north of this would be the peripheral local groups, the Neurs, remaining under the strong influence, possibly even political and military, of the Scythian center. It is for these reasons that one should retract from distinguishing (for the Early Iron Age) the Lezhnica and Cherepin-Lagodiv groups and consider abandoning previous interpretations. Emphasizing their syncretic character so strongly does not fully explain the evidence and is more like an ineffective picklock than a real key to observing the realities of early Iron Age life in Volhynia and western Podolia.

Translated by Iwona Zych 


\section{WYKAZ CYTOWANEJ LITERATURY}

\section{BIBLIOGRAPHY OF WORKS CITED}

Adamik-Proksa J., O cadryga-Toka r czyk E. 2020, Problem chronologii zolnika z grodziska $w$ Chotyńcu i tworzacych go poziomów użytkowych w świetle badań nad klasyfikacja i datowaniem szpil, „Przegląd Archeologiczny” (in print).

A le k s e e v A. U. 2003, Hronografiâ Evropejskoj Skifii VII-IV vekov do n.è., Sum.: The Chronography of European Scythia $\left(7^{\text {th }}-4^{\text {th }}\right.$ centuries BC), Sankt-Peterburg.

B a n d r i v s' ki j M. 2002, Mogil'nik v Petrikovì bilâ Ternopolâ v kontekstì pohoval'nogo obrâdu visoc'koï kul'turi, Zusamm.: Das Gräberfeld in Petrykiw bei Ternopil im Kontext des Begräbnisritus der Wysotsko-Kultur, L'vìv.

B a ndrivs'kij M. 2005, Visoc'ka kul'tura ta ï shidnì zv'âzki, [in:] Na pošanu Sofii Stanislavivni Berezanskoï, V.V. Otroŝenko ed., Kï̀v, pp. 241-252.

B a ndrivs'kij M. 2014, Kul'turno-istoričnì procesi na Prikarpattì ì Zahidnomu Podillì v piznij period epohi bronzi - na počatku dobi rann'ogo zaliza, Sum.: Cultural and historical processes in Sub-Carpathian and West Podolian regions during the Late Bronze Age - the beginning of Early Iron Age, L'vì.

B a d rivs'kij M., Bilik M., Zubik R. 2012, Kins'ka uprâžzi skarbu z Bìrok Velikih âk indikator postvisoc'kogo gorizontu na ternopils'komu plato, Sum.: Horse tack from the hoard in Birky Velyki as an identificator of Post-Vysotska culture's horizon on Ternopil plateau, „Materìali i doslìdžennâ z arheologiï Prikarpattâ ì Volinì”, 16, pp. 463-474.

B a n d rivs'kij M., Kr u šel'n i c'k a L. İ. 1998, Ossnovni periody rozvitku visoc'koï kul'turi (za materialami pohoval'nih pam'âtok), „Zapiski NTŠ. Pracì arheologìčnoï komìsiì”, 235, pp. 193-247.

B a ndrivs'kij M., Kr u šel'n i c'k a L. İ. 2012, Zolotì Mihalkivs'ki skarbi ta ïh dola, Sum.: Gold Mykhalkiv hoards and their history, L'vì.

B u rghard t M. 2020, Classification and chronology of the collection of arrowheads from ash-hill found in hillfort of the Scythian cultural circle in Chotyniec, site 1, Jarosław district, „Sprawozdania Archeologiczne” (in print).

B u k ow sk i Z. 1966, W sprawie genezy i rozwoju grupy wysockiej kultury łużyckiej, Sum.: On the origins and development of the Wysocko Group of Lusatian Culture, „Archeologia Polski”, 11, pp. 28-106.

B u k ow s k i Z. 1977, The Scythian influence in the area of Lusatian Culture, Wrocław.

C h o ch or ow s ki J. 1985, Die Vekerzug-Kultur. Charakteristik der Funde, Kraków.

C h o c h o r o w s k i J. 1993, Ekspansja kimmeryjska na tereny Europy Środkowej, Zusamm.: Die kimmerische Expansion in das mitteleuropäische Gebiet, Kraków.

C h o ch o r o w s k i J. 2014, Scytowie a Europa Środkowa - historyczna interpretacja archeologicznej rzeczywistości, Zusamm.: Die Skythen und Mitteleuropa - historische Deutung der archäologischen Wirklichkeit, „Materiały i Sprawozdania Rzeszowskiego Ośrodka Archeologicznego", 35, pp. 9-58.

C z o p e k S. 2007, Uwagi o możliwościach archeologicznej identyfikacji Neurów, Sum.: Remarks on possibilities of archaeological identification of Neures, [in:] Heac mihi in animis vestris templa. Studia Classica in memory of Professor Lesław Morawiecki, P. Berdowski, B. Blahaczek eds., Rzeszów, pp. 407-422.

$\mathrm{C} z$ o p e k S . 2010a, Einfluss der äußeren Einwirkungen auf die Gestaltung des kleinpolnischen Kulturbildes in der frühen Eisenzeit, [in:] Rola głównych centrów kulturowych w kształtowa- 
niu oblicza kulturowego Europy Środkowej we wczesnych okresach epoki żelaza, B. Gediga, W. Piotrowski eds., Biskupin-Wrocław, pp. 243-263.

C z o p e k S. 2010b, Naddniestrzańskie rubieże kulturowe w epoce brązu i wczesnej epoce żelaza, Zusamm.: Kulturgrenzegebiete am Dnjestr in der Bronze- und Früheisenzeit, [in:] Mente et rutro. Studia archaeologica Johanni Machnik viro doctissimo octogesimo vitae anno ab amicis, collegis et discipulis oblata, S. Czopek, S. Kadrow eds., Rzeszów, pp. 357-368.

Czopek S. 2014, Meandry interpretacji $w$ archeologii funeralnej, „Naukovi Studii”, 7, pp. 18-29.

C z o p e k S . 2018, Od środkowej epoki brązu do wczesnej epoki żelaza. Zmienność kulturowa w epoce brąu $i$ we wczesnej epoce żelaza $w$ dorzeczu Wiszni na tle przemian kulturowych w Europie środkowo-wschodniej, [in:] S. Czopek, K. Trybała-Zawiślak, N. Wojceszczuk, O. Osaulczuk, D. Bobak, P. Gębica, A. Jacyszyn, W. Pasterkiewicz, D. Pawliw, W. Petehyrycz, M. Połtowicz-Bobak, A. Wacnik, Przemiany kulturowo-osadnicze w dorzeczu rzeki Wiszni w epoce brązu i we wczesnej epoce żelaza w kontekście zmian prahistorycznej i wczesnohistorycznej ekumeny, Sum.: Cultural and settlement changes in the Wisznia river basin in the Bronze Age and the Early Iron Age in the context of transformations of prehistoric and early medieval ecumene, Rzeszów, pp. 156-185, 193-210.

C z o p e k S. 2019, Enklawa scytyjskiego kregu kulturowego w południowo-wschodniej Polsce, Sum.: An enclave of the Scythian cultural circle in south-eastern Poland, „Przegląd Archeologiczny", 67, pp. 119-148.

C z op ek S., Krąpi e c M. 2020, The cult area (zolnik) from the hillfort of the Scythian cultural circle in Chotyniec near Radymno (south-eastern Poland) in the context of radiocarbon dating, „Radiocarbon” (in print).

Czopek S., Pawliw D., Petehyrycz W. 2016, Grób grupy zachodniopodolskiej $z$ okresu wczesnoscytyjskiego, Sum.: Burial of the West Podolian Group from the Early Scythian period. Osada z późnej epoki brązu/wczesnej epoki żelaza, Sum.: Settlement from the Late Bronze and Early Iron Ages, [in:] S. Czopek, J. Machnik, W. Pasterkiewicz, D. Pawliw, W. Petehyrycz, Wielokulturowe stanowiska archeologiczne w Bykowie koło Drohobycza, Kraków, pp. 119-150, 451-551.

Czopek S., Trybała-Zawiślak K., Tokarczyk T., Ocadryga-Tokarczyk E., Burghardt M., Adamik-Proksa J., Rajpold W. 2017, Pierwsze sprawozdanie $z$ weryfikacyjnych badań na grodzisku $z$ wczesnej epoki żelaza $w$ Chotyńcu, Zusamm.: Der erste Bericht aus den Verifikationsforschungen in dem früheisenzeitlichen Burgwall in Chotyniec, „Materiały i Sprawozdania Rzeszowskiego Ośrodka Archeologicznego", 38, pp. 291-305.

Czopek S., Trybała-Zawiślak K., Wojceszczuk N., Osaulczuk O., Bobak D., Gębica P., Jacyszyn A., Pasterkiewicz W., Pawliw D., Petehyrycz W., Połtowicz-Bobak M., Wacnik A. 2018, Przemiany kulturowo-osadnicze $w$ dorzeczu rzeki Wiszni w epoce brazu i we wczesnej epoce żelaza w kontekście zmian prahistorycznej i wczesnohistorycznej ekumen, Sum.: Cultural and settlement changes in the Wisznia river basin in the Bronze Age and the Early Iron Age in the context of transformations of prehistoric and early medieval ecumene, Rzeszów.

C z o p e k S., W o j c e s z c z u k N. 2018, Charakterystyka bazy źródłowej, [in:] S. Czopek, K. Trybała-Zawiślak, N. Wojceszczuk, O. Osaulczuk, D. Bobak, P. Gębica, A. Jacyszyn, W. Pasterkiewicz, D. Pawliw, W. Petehyrycz, M. Połtowicz-Bobak, A. Wacnik, Przemiany kulturowo-osadnicze $w$ dorzeczu rzeki Wiszni w epoce brazu $i$ we wczesnej epoce żelaza w kontekście zmian prahistorycznej i wczesnohistorycznej ekumen, Sum.: Cultural and set- 
tlement changes in the Wisznia river basin in the Bronze Age and the Early Iron Age in the context of transformations of prehistoric and early medieval ecumene, Rzeszów, pp. 30-43.

D a ra ga n M. N. 2004, Periodisierung und Chronologie der Siedlung Žabotin, „Eurasia Antiqua”, 10, pp. 55-146.

D ą b r o w s k i J. 1972, Powiązania ziem polskich z terenami wschodnimi w epoce brązu, Sum.: Connections of Polish lands with eastern territories in the Bronze Age, Warszawa.

$\mathrm{D} z \mathrm{i}$ ę g i e le w s k i K. 2017, Late Bronze and Early Iron Age communities in the northern part of Polish Lowland (1000-500 BC), [in:] The Past Societies, 3, U. Bugaj ed., Warszawa, pp. 295-340.

È b e r t s H. 2012, Problema interpretacji pogrebal'nyh obrâdov Zapadno-Podol'skoj grupy ranneskifskoj kul'tury, [in:] Kul'tury stepnoj Evrazii i ih vzaimodejstvie s drevnimi civilizaciâmi, 2, V.A. Alëkšin, E.V. Bobrovskaâ, M.T. Kašuba, L.B. Kirčo, S.B. Krasnienko, V.P. Nikonorov, M.N. Pšenicyna, M.B. Ryspin, D.G. Savinov, L.A. Sokolova, V.Â. Stëganceva eds., Sankt-Peterburg, pp. 325-332.

G a w li k A . 2005, Znaleziska scytyjskie w zasieggu kultury wysockiej, Zusamm.: Die skythischen Funde aus dem Verbreitungsbereich der Wysocko-Kultur, [in:] Problemy kultury wysockiej, S. Czopek ed., Rzeszów, pp. 205-219.

Gawlik A., Przybyła M.S. 2005, Początki wczesnej epoki żelaza w Kotlinie Sandomierskiej, Zusamm.: Der Beginn der frühen Eisenzeit im Sandomierz-Becken, [in:] Archeologia Kotliny Sandomierskiej, M. Kuraś ed., Stalowa Wola, pp. 313-352.

G e j k o A. 2011, Gončarstvo naselennâ skifs'kogo času Dniprovskogo Lisostepnovogo Livoberežžâ, Poltava.

Godlewski P. 2005, O nowych możliwościach datowania początków kultury wysockiej, Zusamm.: Über die neuen Datierungsmöglichkeiten der Anfänge von Wysocko-Kultur, [in:] Problemy kultury wysockiej, S. Czopek ed., Rzeszów, pp. 33-44.

Gu c a l A. 2000, Rudkovec'ke gorodiŝe i peršij pohid skifiv u pridnistrovs'kij lisostep, [in] Davna i sredn’ovična istoriâ Ukraïni, L. Baženov ed., Kam’ânec'Podil's'kij, pp. 69-79.

H o z e r M. 2005a, Historia badań kultury wysockiej, Zusamm.: Geschichte der Forschungen an der Wysocko-Kultur, [in:] Problemy kultury wysockiej, S. Czopek ed., Rzeszów, pp. 21-31.

H o z e r M. 2005b, Stan badań nad kultura wysocka, Zusamm.: Stand der Forschungen an der Wysocko-Kultur, [in:] Problemy kultury wysockiej, S. Czopek ed., Rzeszów, pp. 220-250.

I g n a c z a k M. 2016, Elementy kulturowe lasostepu pontyjskiego we wczesnej epoce żelaza na Niżu Polskim w świetle materiałów ceramicznych (650-520/470 BC), Sum.: Ceramic material as cultural elements of the Pontic forest-steppe in Early Iron Age on the Polish Lowland (650-520/470 BC), Poznań.

Il'č i š i n V., G r e čko D. 2018, Doslidžennâ bronzolivarnoï majsternì rann'oskifs'kogo času bila sela Gončarìvka Zoločivs'kogo rajonu na L'vìvsinnni, „Arheologìčnì Doslìdžennâ v Ukraìnì 2016", Kïiv, pp. 127-129.

Kło s ińs k a E. 2005, Na południowo-wschodnich peryferiach popielnicowego świata - sytuacja kulturowa i osadnicza w młodszej epoce brązu i we wczesnej epoce żelaza $w$ dorzeczu Huczwy i górnego Bugu, Zusamm.: Auf den südöstlichen Grenzgebieten der Urnenfelderwelt - kulturelle und Besiedlungssituation in der jüngeren Bronzezeit und frühen Eisenzeit im Einzugsgebiet von der Huczwa und dem oberen Bug, [in:] Problemy kultury wysockiej, S. Czopek ed., Rzeszów, pp. 161-192.

Kło s ińs ka E. M. 2007, Lubelszczyzna i Ukraina w młodszych odcinkach epoki brązu $i$ we wczesnej epoce żelaza - pytania o losy wspólne i niewspólne, Sum.: The Lublin Region and the Ukraine in the younger stages of the Bronze Age and in the Early Iron Age - inquiries 
into the common and not so common history, [in:] Wspólnota dziedzictwa archeologicznego ziem Ukrainy i Polski, L. Bakalarska ed., Warszawa, pp. 226-249.

Kło s in ska E. M. 2013, Research problems of the Lusatian culture in the Early Iron Age in the Lublin region in the light of new archaeological findings, [in:] Z badan nad kultura społeczeństw pradziejowych i wczesnośredniowiecznych. Księga Jubileuszowa dedykowana Profesorowi Bogusławowi Gedidze w osiemdziesiąta rocznice urodzin przez przyjaciół, kolegów i uczniów, J. Kolenda, A. Mierzwiński, S. Moździoch, L. Żygadło eds., Wrocław, pp. 349-364.

Kowalski - Biłokryły y J. 2012, Chronologia grupy zachodniopodolskiej scytyjskiego kregu kulturowego, Sum.: Chronology of the West-Podolian group of Scythian cultural circle, „Materìali i doslìdžennâ z arheologii Prikarpattâ ì Volini”, 16, pp. 160-189.

K o z a k D. 2012, Poselennâ Nevriv, Slov 'ân ta Germanciv na Stirì, Kï̀v.

Krąpie c M. 2014, Datowanie bezwzględne próbek drewna ze stanowisk: Grabowiec stan. 1 i Hruszowice-Gaje stan. 2, woj. podkarpackie, Sum.: Absolute dating of wood samples from sites: Grabowiec site 1 and Hruszowice-Gaje site 2, the Podkarpackie Voivodeship, „Raport”, 9, pp. 165-167.

Kr ušeln i cka L. 1979, Studien zur Besiedlung der ukrainischen Karpaten und des Karpatenvorlandes zu Beginn der Eisenzeit, „Acta Archaeologica Carpathica”, 19, pp. 73-97.

Kr u š e l'n i c' k a L. İ. 1976, Pivnične Prikarpattâ i zahidna Volin'za dobi rann'ogo zaliza, Kiïv. K r ušel'n i c'ka L. İ. 1990, Vysockaâ kul'tura. Kul'tury ranneskifskogo perioda verhnego Poddnestrov'â i zapadnoj Volyni. Ranneskifska kul'tura v zapadnom Podol'e, [in:] Arheologiâ Prikarpat 'â, Volyni i Zakarpat 'â (èneolit, bronza i rannee železo), A. P. Černyš ed., Kiev, pp. 115-122, 143-157.

Kr u šel'n i c'ka L.İ. 1993, Ležnic'ka grupa pamâtok Volini. Čerepins'ko-lagodivs'ka grupa pam'âtok, [in:] Pamâtki galšstats'kogo periodu v mežiričči Visli, Dnistra i Prip 'âti, L. Krušel'nic'ka ed., Kiïv, pp. 143-239.

K r u še l'n i c'k a L. İ. 1998, Čornolis'ka kul'tura Seredn'ogo Pridnistrov'â, Zusamm.: Die Tscharnoless-Kultur des mittleren Dnister-Raumes, L'vìv.

Kr ušel'n i c'k a L. İ., Ma le e v U. N. 1990, Plemena kul'tury frakijskogo galštata (Gava-Goligrady), [in:] Arheologiâ Prikarpat'â, Volyni i Zakarpat 'â (èneolit, bronza i rannee železo), A.P. Černyš ed., Kiev, pp. 123-135.

Ł aw n i z zak M., I g n a z a k M. 2016, Macrospatial analysis of early Scythian fortified settlements in the right-bank of Ukraine, „Baltic-Pontic Studies”, 21, pp. 7-26.

Ławniczak M., Ignaczak M., Makohonienko M., Boltryk J. 2019, Grodziska z czasów scytyjskich na prawobrzeżnej Ukrainie. Analiza makroprzestrzenna, [in]: Vir Bimaris. Od kujawskiego matecznika do stepów nadczarnomorskich. Studia z dziejów międzymorza bałtycko-pontyjskiego ofiarowane Profesorowi Aleksandrowi Kośko, M. Szmyt, P. Chachlikowski, J. Czebreszuk, M. Ignaczak, P. Makarowicz eds., Poznań, pp. 861-872.

M e d v e d s k â I. N. 1992, Periodizaciâ skifskoj arhaiki i derevnij Vostok, Sum.: The periodisation of the Scythian archaic period and the Ancient Orient, "Rossijska Arheologiâ", 3/1993, pp. 86-107.

Mel ûkova A.I. 1989, Geografiâ i etnogeografâ Skifii v trudah sovetskih učenyh. Skifskie pamâtniki stepi Severnogo Pričernomorầ, [in:] Stepi evropejskoj časti SSSR v skifo-sarmatskoe vremâ, A.I. Melûkova ed., Moskva, pp. 40-67.

Michalski J. 1982, Pracownia odlewnictwa brązu w Zawadzie, woj. tarnobrzeskie, Zusamm.: Gießereiwerkstatt in Zawada, Wojew. Tarnobrzeg, „Pamiętnik Muzeum Miedzi”, 1, pp. 199-207. 
Moskwa K. 1976, Kultura łużycka w południowo-wschodniej Polsce, Zusamm.: Die Lausitzer Kultur im südöstlichen Gebiet Polens, Rzeszów.

M o s kw a K. 1982, Tendencje rozwoju grupy tarnobrzeskiej kultury łużyckiej, Zusamm.: Die Entwicklungstendenzen der Tarnobrzeg-Gruppe der Lausitzer Kultur, [in:] Południowa strefa kultury łużyckiej i powiązania tej kultury z Południem, M. Gedl ed., Kraków-Przemyśl, pp. 301-315.

Mos z y ń s k i K. 1954, O Neurach Herodota, „Lud”, 41, pp. 134-152.

Mo z olevskij B. M. 2013, Etnična geografiâ Skifï̈, Kì̀v.

Murzìn V. Û. 1998, Naselennâ Ukraïni za skifo-sarmats'koï dobi, [in:] Davnâ istoriâa Ukrä̈ni v troh tomach, 2, Skifo-antična doba, S.D. Križickij, V.M. Zubar, S.S. Besonova, V.Û. Murzìn, A.S. Rusâèva, Ė.V. Černenko eds., Kiïv, pp. 34-153.

O t r o ŝ e n k o V. V. 1998, Bronzovij vik, [in:] Davnâ istoriâ Ukraïni v troh tomach, 1, Pervisne suspil'stvo, V.N. Stanko, S.S. Berezans'ka, V.M. Gladilìn, M.I. Gladkih, V.V. Otroŝenko eds., Kiïv, pp. 384-529.

Pet r e n k o V. G. 1978, Ukrašeniâ Skifii VII-III vv. do n.è, Arheologiâ SSSR, Svod Arheologičeskih Istočnikov, D4-5, Moskva.

P e tr e n k o V.G. 1989, Lokal'nye grupy skifoobraznoj kul'tury lesostepi Vostočnoj Evropy, [in:] Stepi evropejskoj časti SSSR v skifo-sarmatskoe vremâ, A.I. Melûkowa ed., Moskva, pp. 67-80.

Ry b a k ov B. A. 1979, Gerodotova Skifiâ, Moskva.

Shelekhan O., Lifantii O., Boltryk Y., Ignaczak M. 2016, Research in the central part of Severynivka hillfort (Quadrats F80, F90, G71, G81), „Baltic-Pontic Studies", 21, pp. 91-218.

S mi r n ova G. I. 2004, Sostoânie izučeniâ Zapadno-Podol'skoj grupy pamâtnikov ranneskifskogo vremeni v lesostepnoj Skifii v konce XX veka, [in:] Kimmerowie, Scytowie, Sarmaci. Księga poświęcona pamięci Profesora Tadeusza Sulimirskiego, J. Chochorowski ed., Kraków, pp. 409-429.

Sulimirski T. 1931, Kultura Wysocka, Kraków.

S u li m i rski T. 1936, Scytowie na zachodnim Podolu, Lwów.

Tr a ch s el M. 2004, Untersuchungen zur relativen und absoluten Chronologie der Hallstattzeit, Universitätsforschungen zur Prähistorischen Archäologie, 104, Bonn.

Tr y b a ła - Z a w iśl a k K. 2019, Wczesna epoka żelaza na terenie Polski południowo-wschodniej - dynamika zmian i relacje kulturowe, Sum.: The Early Iron Age in south-eastern Poland - dynamics of changes and cultural relations, Rzeszów.

Wę g r z y n o w i c z T. 2001, Zabytki z epoki brązu i wczesnej epoki żelaza z Ukrainy i Białorusi w zbiorach Państwowego Muzeum Archeologicznego w Warszawie, Sum.: Bronze and Early Iron Age artifacts from Ukraine and Belarus in the collections of PMA - State Archaeological Muzeum in Warszawa, Warszawa. 